\title{
Climatic change and its relationship with human society in northern Japan since the mid-Holocene - Quantitative reconstruction of atmospheric and sea surface temperature -
}

Hodaka Kawahata ( $\nabla$ kawahata@aori.u-tokyo.ac.jp )

The University of Tokyo https://orcid.org/0000-0003-4236-7356

Yoshiki Hatta

The University of Tokyo

Hiroto Kajita

The University of Tokyo

\section{Yuki Ota}

The University of Tokyo

\section{Yoshida Akihiro}

Kagoshima University

\section{Kenji Nishina}

RIEEG

\section{Tomoya Aono}

Tohoku university of art and design

Junko Habu

University of California Berkeley

Research article

Keywords: Temperature, Climatic change, East Asian summer monsoon, ENSO(El Niño / La Niña), Medieval Warm Event, Jomon, Ainu, Okhotsk, Holocene, Japan

Posted Date: June 4th, 2020

DOl: https://doi.org/10.21203/rs.3.rs-32694/v1

License: (1) This work is licensed under a Creative Commons Attribution 4.0 International License.

Read Full License 
1 Climatic change and its relationship with human society in northern Japan since the mid-

2 Holocene - Quantitative reconstruction of atmospheric and sea surface temperature -

3

4 Hodaka Kawahata $^{a, b, c *}$, Yoshiki Hatta ${ }^{a, b}$, Hiroto Kajita ${ }^{a, b}$, Yuki Ota ${ }^{a, c}$, Akihiro Yoshida ${ }^{d}$, Kenji

5 Nishina $^{e}$, Tomoya Aono ${ }^{f}$ Junko Habu $^{g, h}$

6

7 a Atmosphere and Ocean Research Institute, The University of Tokyo, Kashiwanoha 5-1-5, Kashiwa,

8 Chiba 277-8564, Japan

9 b Faculty of Science, The University of Tokyo, 7-3-1 Hongo, Bunkyo, Tokyo 113-0033, Japan

10 c Geological Survey of Japan, National Institute of Advanced Industrial Science and Technology

11 (AIST)

12 d Faculty of Law, Kagoshima University, Korimoto 1-21-24, Kagoshima 890-8580, Japan

13 e Research Institute of Energy, Environment and Geology, Hokkaido Research Organization, 19 jou

1412 chome, Kita-ku, Sappro, Hokkaido, 060-0819, Japan

15 f Tohoku university of art and design, 3-4-5, Kamisakurada-machi, Yamagata-city, Yamagata, 990-

169530 Japan

$17 \mathrm{~g}$ Department of Anthropology, University of California, Berkeley, 232 Kroeber Hall, Berkeley, CA

18 94720-3710, USA

19 h Research Institute for Humanity and Science, 457-4 Motoyama, Kamigamo, Kita-ku, Kyoto, 603-

20 8047, Japan

21

22 Correspondence to:

23 H. Kawahata

24 kawahata@aori.u-tokyo.ac.jp

25

26 Keywords

27 Temperature, Climatic change, East Asian summer monsoon, ENSO(El Niño / La Niña), Medieval

28 Warm Event, Jomon, Ainu, Okhotsk, Holocene, Japan 


\section{Abstract}

For the prediction for future climate, it is required to enhance our understanding of the Holocene

33 climatic change. By estimating paleo-temperature, we attempted to examine the relationship

34 between climatic changes and human activities in northern Japan. The alkenone SSTs showed a variation of

$358.7^{\circ} \mathrm{C}\left(14.5^{\circ} \mathrm{C}\right.$ to $\left.23.2^{\circ} \mathrm{C}\right)$. Jomon people living around Funka Bay were more dependent on marine

36 products than in Honshu due to cooler climatic conditions. There are two Hypsithermal environments at

37 Funka Bay around $4.6 \mathrm{cal}$. kyr BP and $1.2 \mathrm{cal}$. kyr BP. Sea levels for the last $7 \mathrm{kyrs}$ have been controlled

38 mainly by local/regional tectonic vertical movement. Therefore, the highstand never always corresponded

39 to Hypsithermal environments. More than one driving forcing, rather than one, may control

40 climatic/environmental change. The $4.2 \mathrm{ka}$ event in northern Japan could be characterized by cooling by a

41 few degrees by the combination of reduced ESAM and El Niño mode. Another notable cooling event

42 occurred in 1.0-0.8 cal. kyr BP due to the La Niña condition and reduced solar activities, which means that

43 the Japanese archipelago never experienced Medieval Warm Event: instead, there was a Medieval Cold

44 Event in Japan. The Okhotsk culture in Hokkaido prospered only under the Hypsithermal condition during

45 the $5^{\text {th }}-9^{\text {th }}$ centuries and subsequently it declined and was incorporated into the Satsumon culture under the

46 cooler environmental conditions. For the Yayoi-era (2.9 cal. kyr BP-) and the following periods, our results

47 are consistent with the previous results from Hiroshima Bay, western Japan, that cold periods $\left(6^{\text {th }}-7^{\text {th }}\right.$

48 century $\mathrm{BC}, 3^{\text {rd }}$ century $\mathrm{BC}, 6^{\text {th }}$ century $\mathrm{AD}, 10^{\text {th }}-12^{\mathrm{h}}$ century $\mathrm{AD}$ and $16^{\text {th }}$ century $\mathrm{AD}$ ) coincided with

49 major shifts in social systems in Japan. 
52

\section{Background}

The Holocene is an important period because of the worldwide dispersal of the human species and its consequences. Notable changes during this period include the development of major civilizations and dramatic shifts toward urban lifeways through to the present (e.g., Weiss et al., 1993; Stanley et al., 2003; Habu, 2004). Currently some anthropogenic activities have significant direct or indirect influences on the environments on a global scale, including global warming, desertification, ocean acidification, pollution, and deforestation (e.g., Kawahata et al., 2019). It is required for us to understand natural processes more deeply in order to predict future climatic changes by distinguishing anthropogenic climatic/environmental change from non-anthropogneic variability.

The oldest evidence for a prosperous hunter- fisher-gatherer culture known as the Jomon culture is dated to approximately $16.5 \mathrm{cal}$. kyr BP, around which the world's earliest known stone arrowheads and pottery were produced in northern Japan during the coldest episode. The Jomon period continued through to 2.9 cal. kyr BP (ca. 2.3 cal. kyr BP in northeastern Japan) (e.g., Fujio et al., 2005; Taniguchi, 2006; Habu, 2008). Jomon archaeological sites in the northern Tohoku region and Hokkaido of Japan provide a unique testimony to a prehistoric culture that left sedentary settlements based on hunting, fishing and gathering (http://jomon-japan.jp/en/) (Figs. 1a, 1b). Among these, Ofune, Kakinoshima, Irie-Takasago, and Kitakogane sites in Hokkaido are located near Funka Bay (e.g., settlements, shell middens, and wetlands). Scholars suggest that these sites were associated with affluent societies with advanced technologies and rich spiritual elements even though they never relied on rice cultivation or the domestication of other cereals. One of the most famous and well-studied mid-Holocene Jomon archaeological sites is the SannaiMaruyama site in northern Japan, the occupation of which started at $5.9 \pm 0.1 \mathrm{cal}$. kyr BP just after the eruption of Towada volcano at $6.0 \mathrm{cal}$. kyr BP. The size of the settlement, 24 hectares, is extraordinarily large. The occupation of this settlement ended at regional/global $4.2 \mathrm{ka}$ event with a sudden cooling by $2.0^{\circ} \mathrm{C}$ (Habu, 2004; 2008; Kawahata et al., 2009b; Kariya et al., 2016). The site remained uninhabited until the $9-10^{\text {th }}$ century $\mathrm{AD}$ (http://sannaimaruyama.pref.aomori.jp/english/) of the early warm Heian Period (Fig. 1b). At 4.2 cal. kyr BP, major civilizations in other parts of the world, including the North Mesopotamian Civilization, the Old Kingdom in Egypt, and the Yangtze River Civilization, also declined (Weiss et al., 1993; Parker et al., 2006, Stanley et al., 2003; Riel, 2008, Zhang, 2013).

The practice of an intensive rice agriculture in paddy fields were introduced at around $2.9 \mathrm{cal}$. kyr BP by immigrants from the Asian continent under the notable cold climate/environment (Wang et al., 2011). The introduction of metallurgy (bronze and iron) for mirrors and weapons are dated just after this period. These changes were followed by a significant population increase. People lived in permanent farming 
villages, accumulated wealth through land ownership and the storage of grain with society more stratified and complex. Based upon the reconstructed SSTs in Hiroshima Bay, western Japan, Kawahata et al. (2017b) argued that the beginning and collapse of aristocratic politics corresponded to notable cold periods. i.e., there is a positive correlation between the prosperity of the early state and climate.

Turning eyes to Europe, for later historic periods, the Roman Warm Period (RWP, 50-400 AD), the Medieval Warm Period (MWP, ca. 950-1250 AD [1000-1400 AD in certain areas]), the Dark Ages Cold Period (AD 500-900) and the Little Ice Age (LIA, ca. 1600-1850 AD [1350-1850 in certain areas]) have received much attention from climatic and historical points of view (e.g., Yan et al., 2011). The RWP and MWP are often called the Roman and Medieval climatic optima respectively, both of which proposed to have been the period of unusually warm weather in Europe and the North Atlantic (e.g., Mann et al., 2009). The time range of, and the affected areas by, MWP are still open to debate. Bradley et al. (2003) concluded that the warmest MWP atmospheric temperatures (ATs) were not synchronous around the globe based upon compiled lines of evidence. On the other hand, LIA was often identified in the regional/global scale. According to the IPCC Assessment Report (2001), it is suggested that LIA is represented as a modest cooling in the Northern Hemisphere and that it was largely an independent regional climate change rather than a globally-synchronous increased glaciation. Although it has been reported that climatic events could be triggers to transform a society, until now, most of the reconstructed temperature data are qualitative or semi-quantitative (e.g., deMenocal, 2001; Haug et al., 2003). In order to understand a causal relationship between climate/environmental and social changes, quantitative reconstruction of paleo-temperature is required.

\section{Problematic}

The mid-latitude zone of the northwestern North Pacific is a sensitive area in terms of the regional and global climate change. The northern westerly wind, which is overlying this region, meanders between warm and cold air mass and brings the continental material such as eolian dust (Fig. 1a) (e.g., Kawahata et al., 2000). Also the Kuroshio Current and its branches, Tsushima and Tsugaru Currents, carry heat energy from low latitude to warm up this region, while the Oyashio Current flows from the northern North Pacific to cool down the coasts of Hokkaido and Tohoku regions (e.g., Takei et al., 2002; Sagawa et al., 2014; Horikawa et al., 2015). The oscillation in cooling/warming could be controlled by climate modes, such as the El Niño-Southern Oscillation (ENSO), the Asian Monsoon System and other atmosphere-ocean interactions (e.g., Yamamoto, 2009; He et al., 2015; Tada et al., 2016a, b). In addition, other factors such as solar activity, insolation, and sea level change also influence climatic/environmental change. Previous studies indicate that the temperature fluctuations cannot be explained by a single cause but rather by more 
than one external and internal driver of climate variability. It is crucial to understand which factors could

117 play a more important role in SST events in the Holocene.

\section{Objective}

Coastal sediments collected from bays provide a special advantage to present quantitative estimates of summer AT based upon the high correlation between AT and sea surface temperature (SST) (Kawahata et al., 2017a, b). In this study, we reconstruct paleo- alkenone SSTs quantitatively with a high time resolution in northern Japan by collecting sediments from semi-closed Funka Bay (Fig. 1a, 1b). This paper evaluates the processes behind climatic/environmental change, especially events since the mid-Holocene and discusses the ecodynamics between climatic/environmental changes and human activities in Hokkaido, including the lives of Jomon and Okhotsk peoples in relation to the subsequent development of the Ainu culture.

\section{Study areas and materials}

\section{Study area}

Funka (Uchiura) Bay, $30 \mathrm{~km}$ in diameter and over $90 \mathrm{~m}$ in depth, is located between Hakodate and Muroran Cities in southern Hokkaido (Fig. 1a, 1b). The surface sediments are composed mainly of mud, sometimes of sand, along the shallow coast in semi-enclosed bay. The term "Funka" in Japanese means volcanic eruptions because several active volcanoes such as Mt. Hokkaido Komagatake, Mt. Usu, Mt. Showa-shinzan, Mt. Yotei, and Mt. Tarumae are located around the bay. In particular, Mt. Komagatake, which is $1,131 \mathrm{~m}$ above the sea level, is an active andesitic strato-volcano. Its major eruption was recorded at $1640 \mathrm{AD}$ with volcanic debris of $2.9 \mathrm{~km}^{3}$ after roughly 5,000 years of dormancy (Katsuki et al., 1989; Geological Survey of Japan, 2017). Subsequently, three additional smaller eruptions occurred in 1694 AD $\left(0.36 \mathrm{~km}^{3}\right), 1856 \mathrm{AD}\left(0.21 \mathrm{~km}^{3}\right)$ and $1929 \mathrm{AD}\left(0.34 \mathrm{~km}^{3}\right)$.

SSTs in the bay are influenced by the two major ocean currents, the Tsugaru and Oyashio Currents. The warm Tsugaru Current reaches the bay from the southeast and makes a left-hand (anticlockwise) turn mainly in the summer while the cold Oyashio Current flows into the bay from the northeast and shows a right-hand (clockwise) flow in the other seasons (http://www.fsc.hokudai.ac.jp/muroran/lab.html). The

142 Tsugaru Current shows higher salinity and lower nutrient concentration, while the Oyashio Current is

143 famous for lower salinity and higher nutrients. Meteorological Institute (2015) provides a monthly record of meteorological parameters such as AT, 
$\mathrm{mm}$ (https://weather.time-j.net/Stations/JP/muroran). Although the annual mean AT is $8.6^{\circ} \mathrm{C}$, August and

148 January are the warmest and coldest months, respectively. The maximum, average and minimum monthly149 mean ATs in August are $23.4,20.5,18.5^{\circ} \mathrm{C}$ respectively, while those in January are $0.3,-2.0$ and $-4.2^{\circ} \mathrm{C}$.

150 During the same period, Muroran Marine Station of Hokkaido University provided a monthly record of 151 SSTs (http://www.fsc.hokudai.ac.jp/muroran/english/). The maximum and minimum monthly-mean SSTs 152 were $20.1^{\circ} \mathrm{C}$ (August) and $3.5^{\circ} \mathrm{C}$ (February), respectively. The monthly AT and SST are particularly well 153 correlated during summer (June through September). (AT $=0.7899 x S S T+4.26 ; \mathrm{r}=0.89, p=0.001$ ). versus depth, resulting in steep gradient of water density (Miyake et al., 1977). The annual rainfall and duration of insolation are $1,185 \mathrm{~mm}_{\text {year }}{ }^{-1}$ and $1,725 \mathrm{~h}_{\text {year }}{ }^{-1}$, respectively. The wind is generally $3.5 \mathrm{~m} \mathrm{~s}^{-1}$ in summer and $6.0 \mathrm{~m} \mathrm{~s}^{-1}$ in winter. Wind direction is the east-northeast in summer and the west-northeast in the other seasons.

\section{Sediment samples}

A total length of $731 \mathrm{~cm}$ of core St. 5 was collected at a distance of only $7.8 \mathrm{~km}$ from the coast and at a water depth of $64 \mathrm{~m}$ at $42^{\circ} 23^{\prime} 59.377^{\prime \prime} \mathrm{N} ; 1^{\circ} 0^{\circ} 2^{\prime}$ ' in Funka Bay during the research program by Geological Survey of Hokkaido in 2010 (Fig. 1a). Based upon seismic survey, the $20 \mathrm{~m}$ thick surface sediments were not disturbed, which demonstrates that the sedimentary particles have been deposited continuously (Hokkaido Research Organization, National Institute of Advanced Industrial Science and Technology, 2011). The sediments were generally composed of dark olive homogeneous mud with ash layers in shallow depths.

\section{Analytical Procedures}

The core description and the analysis of magnetic susceptibility (MS) were carried out just before collecting samples, which enabled us to identify ash layers.

A total weight of $<12 \mathrm{mg}$ of plants and molluscan shells was selected for accelerator mass spectrometry (AMS) radiocarbon dating at the Beta Analytic in USA (Table 1). The detailed procedures used are described at their web site of http://www.radiocarbon.com. procedures used are described in Minoshima et al. (2007) and Kawahata et al. (2009a). The targeted organic materials were extracted with an accelerated solvent extractor (ASE-200, Dionex, California, USA) and an automatic solid-phase extraction system (Rapid Trace SPE Workstation, Zymark, UK) from $3 \mathrm{~g}$ of 
Hewlett Packard 6890 series gas chromatograph equipped with an on-column injector, an Agilent HP-5ms

179 fused silica column $(60 \mathrm{~m} \times 0.25 \mathrm{~mm})$, and a flame ionization detector. Several procedural blanks, which

180 were analyzed in parallel with the sample analyses, showed no C37 alkenone contamination. The analytical error for $\mathrm{UK}^{\prime}{ }_{37}$ (defined as [37:2]/\{[37:2] $\left.\left.+[37: 3]\right\}\right)$ was \pm 0.0060 based on the results of five replicate analyses. As pointed out by Villanueva and Grimalt (1997), irreversible adsorption of C37:3 on the chromatographic column is often a major source of error when the total amount of C37 alkenone injected into the system for analysis is $<5 \mathrm{ng}$. Therefore, the error should be minimized in this study because $>5 \mathrm{ng}$ was used in each injection.

In this study, SSTs were calculated by assuming a linear relationship between SST and C37 alkenone unsaturation and using the empirical equation reported by Prahl et al. $(1988): \mathrm{U}^{\prime}{ }_{37}=0.034 \mathrm{~T}\left({ }^{\circ} \mathrm{C}\right)+$ 0.039. Therefore, the estimated alkenone SST has error of $0.2^{\circ} \mathrm{C}$ at its best.

\section{Results}

190

\section{Age model}

The thick ash layer at $46 \mathrm{~cm}$ depth can be identified by visual inspection and magnetic susceptibility profiles, which contains pyroxene and plagioclase as phenocrysts and white color glass with rough surface (Miyazono and Nishina, 2007) (Fig. 2). It can be estimated to originate from the large Komagatake eruption at 1640AD (Ko-d) after the dormant period over 5000 years (Geological Survey of Japan, 2017) because the other volcanic products from subsequent eruptions, such as Komagatake (Ko-c1, Ko-c2), Tarumae (Ta-a, Ta-b) and Usu (Us-1663), have not accumulated in Funka Bay (Nakamura, 2016), Small increase of magnetic susceptibility at $66 \mathrm{~cm}$ may be compared with the unknown Tsunami deposit just below Ko-d, which is identified in the wide area of southern Hokkaido (Nakanishi and Okamura, 2019).

The ${ }^{14} \mathrm{C}$ dating results from plant and shell samples are shown in Table 1 . They were converted to calendar ages using the Oxcal ver. 4.2.4 software (Ramsey and Lee, 2013) with the Intcal 13 and Marine 13 datasets (Reimer et al., 2013). In the case of marine shells, a regional specific reservoir $(\Delta R)$ correction of $34 \pm 12$ years reported in the southern Hokkaido was incorporated into the calculation (Yoneda et al., 2007). Based on these calibration methods, the age of the plant collected from a depth of $700 \mathrm{~cm}$ was in good agreement with the age of the shell collected from the depth of $702 \mathrm{~cm}$ (Table 1a). This confirms that our age model is reasonably accurate. In the age model construction for the Core St.5, 9 samples were datable because biogenic carbonates were unfortunately dissolved in the organic-rich coastal sediments in spite of the best effort to conduct ${ }^{14} \mathrm{C}$ analysis for all the plant and molluscan shell samples. We excluded three data of \#8, \#10 and \#12 because they were broken and degraded pieces. Extremely strong positive correlation between the adopted ${ }^{14} \mathrm{C}$ ages and those recovered depths $\left(\mathrm{r}^{2}=0.997\right)$ suggests that Core St. 5 provides continuous and constant environmental records since $6700 \mathrm{yr} \mathrm{BP}$. The Ko-d tephra originated 
211 from the Komagatake 1640 eruption was also used as an age control horizon because it completely matches

212 this regression line. On the other hand, the top $30 \mathrm{~cm}$ section provides rough estimate of the age

213 determination because of loose and soft sediment with much water and then our discussion is focused on

214 the sediments below the Ko-d tephra (up to 1640AD) (Table 1, Fig. 2). The ages of sediments for alkenone

215 analysis were calculated assuming a constant sedimentation rate between the age control horizons. The

216 mean sedimentation rate was $108 \mathrm{~cm} \mathrm{kyr}^{-1}$, which was consistent with those obtained in Mutsu, Tokyo and

217 Hiroshima Bays (Table 1b; Kawahata et al., 2009b; 2017b, Kajita et al. 2020).

\section{$218 \quad$ C37 alkenone SST}

The SST was reconstructed based upon the analysis of C37 alkenone. The major alkenone-producing coccolithophorid was Emiliania huxleyi in this area under both the Tsugaru and Oyashio currents (Hagino et al., 2005; Kawahata et al., 2017a; Kawahata, 2019). The major production period of E. huxleyi has been observed in satellite images in summer (June - August) (Takahashi et al., 1995), which is confirmed by the sediment trap experiment at Site MD01-2409 $\left(41^{\circ} 33.8^{\prime}, 141^{\circ} 52.0^{\prime} \mathrm{E}\right)$ under the influences by the Tsugaru current (Fig. 1a) (Kawahata et al., 2009a). A global core-top calibration from 370 sites between $60^{\circ} \mathrm{S}$ and $60^{\circ} \mathrm{N}$ in the Pacific, Atlantic, and Indian Oceans by Müller et al. (1998) is within the error limits of the widely used E. huxleyi culture calibration of Prahl et al. (1988).

The mean alkenone SST in surface-top soft sediments was $21.7^{\circ} \mathrm{C}$, which is nearly the same as the summer (August) SST range $\left(17.7-21.0^{\circ} \mathrm{C}\right.$, mean value of $\left.19.7^{\circ} \mathrm{C}\right)$ during the last 30 years. Since the AT is highly correlated with the SST, as is observed in Mutsu Bay and off Shimokita, the mean monthly AT is almost comparable to the monthly SST around $20^{\circ} \mathrm{C}$ in Funka Bay at the modern condition (Kawahata et al., 2009b; Kawahata et al., 2017a).

The alkenone SSTs varied from $14.5^{\circ} \mathrm{C}$ to $23.2^{\circ} \mathrm{C}$ with a mean value of $18.6{ }^{\circ} \mathrm{C}$ (Fig. 3a). They peaked in 6.4, 4.6, $1.2 \mathrm{cal}$. kyr BP and the present day. Broad maxima occurred in 5.7-4.3 and 2.9-2.1 cal.

$234 \mathrm{kyr}$ BP. Large temperature falls occurred in 6.1-5.9, 4.2-4.1, 3.0, 2.0 and $0.8 \mathrm{cal}$. kyr BP. The results are 235 consistent with the occurrence of a molluscan assemblage including warm water species such as Meretrix 236 lusoria, Mactra veneriformis, Umbonium moniliferum and others, which occurred in 5.0-4.0 and 2.4-2.3 237 cal. kyr BP in southern Hokkaido (Akamatsu et al., 1995; Kito et al., 1998).

Mutsu Bay, which is located on the opposite bank of the straits, showed no definite long-term warming trend of SSTs (ATs) in summer (Figs. 1 and 3a), probably due to a slight difference of the current

240 channel and intensity across the Tsugaru Strait. However, Funka Bay was colder than Mutsu Bay because 241 of higher latitude by $1^{\circ} 30^{\prime}$ and an appreciable influence by the Oyashio Current (Fig. 1a). Also both bays

242 showed low-frequency oscillations of ATs (SSTs) in the millennial-scale to sub-millennial-scale with 243 maxima around 6.4 and 4.6 cal. kyr BP and minima around 5.8 and 4.1 cal. kyr BP respectively (Fig. 3a). 
Temperature is one of the most important parameters for environmental changes. At modern state, the monthly AT and SST are well correlated during summer in semi-enclosed Japanese Bays and coastal areas (e.g., Kawahata 2017a, b) (Fig. 1a). In particular, in Mutsu Bay, both monthly AT and SST are the same from March to August (http://www.mutsuwanbuoy.jp/observation/). Therefore, summer AT can be quantitatively reconstructed because alkenone production occurs primarily in early summer off northern Japan (Yamamoto et al., 2007; Kawahata et al., 2009a). If the correlation between the monthly AT and SST has been valid for the last several thousand years, the ATs around Funka Bay can be calculated to be $16.9^{\circ} \mathrm{C}, 18.5^{\circ} \mathrm{C}, 20.1^{\circ} \mathrm{C}$ and $21.6^{\circ} \mathrm{C}$ in the cases of SSTs of $16^{\circ} \mathrm{C}, 18^{\circ} \mathrm{C}, 20^{\circ} \mathrm{C}$ and $22^{\circ} \mathrm{C}$ respectively. The difference between the ATs and SSTs is so small around $18^{\circ} \mathrm{C}$ (Fig. 3a). The estimated ATs varied from $15.7^{\circ} \mathrm{C}$ to $22.6{ }^{\circ} \mathrm{C}$ with a mean value of $19.0^{\circ} \mathrm{C}$.

\section{Discussion}

\section{Consistency of alkenone SST with bivalve assemblage in Jomon sites}

There are 5 Jomon sites with shell middens around Funka Bay: the Usu 6 site, Kitakogane middens B and C, Wakkaoi midden A, Etomo midden, and Takasago midden C. The distance among these sites are 36 $\mathrm{km}$ or less. Bivalves assemblages at each shell midden were different, depending on the marine ecosystems that were affected by time-series coastal environmental change (Aono, 2017).

Crassostrea gigas accounted for more than $80 \%$ of shells at the Usu 6 site (middle Initial to early

262 Early Jomon) without fish and sea and terrestrial animals. This implies that the site occupants focused their 263 subsistence activities primarily on Crassostrea gigas from autumn to spring as a result of their intentional 264 choice (Aono, 2017). On the other hand, Kitakogane midden B of the early Early Jomon, which seems to 265 have been occupied throughout the year, is characterized by the predominance of Meretrix lusoria, which prefers to inhabit in warm environments (Aono, 2013). In the late Early Jomon, Macridiscus melanges accounted for $58.3 \%$ while Crassostrea gigas, Mytilus coruscus, and Venerupis philippinarum were approximately 10\% each, at Kitakogane midden C (6.0-5.6 cal. kyr BP). Similar characteristics are observed at the Wakkaoi midden. At the bottom layer of Kitakogane midden C, Meretrix lusoria are present. This indicates that the climate cooled down from the early to late Early Jomon (6.2-5.8 cal. kyr, BP). As a result, the percentage of Meretrix lusoria decreased to only $0.2 \%$.

There were no large shell middens around Funka Bay during the warm environmental period of 5.7-

$2734.5 \mathrm{cal}$. kyr BP (Early Jomon - late Middle Jomon). The possibility for the loss of shell midden by the

274 costal erosion due to higher sea level (Fig. 3f) is unlikely, because Jomon people around Funka Bay tended 275 to leave shell middens at relatively higher locations (generally, more than $7 \mathrm{~m}$ above sea level) and because 276 shell middens tended to decrease under the warmer environmental condition in Hokkaido. Mya arenaria 
277 oonogai and Venerupis philippinarum, which are proxies for cool environments, accounted for $41.5 \%$ and

$27833.1 \%$ respectively in 3.98-3.90 cal. kyr BP at the Etomo midden (early Late Jomon). At Takasago midden

279 C (early Late Jomon), the ratios of Venerupis philippinarum, Mytilus coruscus, and Littorina brevicula

280 were $77.7 \%, 4.9 \%$, and $14 \%$ respectively.

281 In summary, from the middle Early Jomon through to early Late Jomon, the dominant shell species

282 changed as follows: Crassostrea gigas (late Initial Jomon) $\rightarrow$ Meretrix lusoria (early Early Jomon) $\rightarrow$

283 Macridiscus melanges (late Early Jomon) $\rightarrow$ Crassostrea gigas (late Early Jomon) $\rightarrow$ No occurrence of

284 shell middens probably due to warm environments (early to mid/late Middle Jomon) $\rightarrow$ Mya arenaria

285 oonogai (early Late Jomon) andVenerupis philippinarum (early Late Jomon). This suggests that the

286 dominant species of bivalve assemblages changed from cool species through warm species to cool species

287 again. This fluctuation trend is consistent with the change in alkenone SST from 6.70 to 3.90 cal. kyr BP.

\section{Mid-Holocene Hypsithermal environments and its relationship with sea level highstand}

Orbital variations have often governed insolation changes, which primarily forced the Holocene

290 Thermal Maximum (HTM), called often as the Hypsithermal period, at high latitude. Precessional

291 culmination occurred in 12-10 ka with total annual insolation of $1 \mathrm{Wm}^{-2}$ higher than the present at $60^{\circ} \mathrm{N}$,

292 which brought HTM in the northwest North America, in 12-9 ka. The local summer temperature was on

293 average $1.6 \pm 0.8^{\circ} \mathrm{C}$ higher than the present. On the other hand, northeastern North America experienced

294 delayed warming peak by 4,000 years due to the cooling by the residual Laurentide Ice Sheet. The early

295 Holocene warming was associated with sea level rise by melting of ice sheet (Kaufman et al., 2004). The

296 linkage between temperature and sea level change is also reported from Hiroshima Bay, located in the Seto

297 Inland Sea. The SST reconstructed by shallow water sediments generally decreased before $7.0 \mathrm{cal}$. kyr BP

298 in response to a decline in insolation and the sea-level rise. A lower sea level could promote warming in the

299 shallower water column. After the sea level was stabilized, even when insolation continued to decrease, the

300 mean temperature fluctuated little (Kawahata et al., 2017b). Although transgression generally works as a

301 warming factor because albedo is higher on the sea than on the land at the regional/global scale, the timing

302 of sea-level highstand is compared with that at the Mid-Holocene Hypsithermal environments in this study.

303 In the case of Funka Bay, insolation change could not have played an important role in SST change

304 because the long-term SSTs' trend seemed to have a reverse profile to the summer insolation. It gradually

305 declined from the middle to the late Holocene in the Northern Hemisphere (Berger, 1978) (Fig. 3b). The

306 eustatic sea level data suggest that meltwater contributions from the major North American and European

307 ice sheets largely ceased by $7.0 \mathrm{cal}$. kyr BP, after which the rate of sea level rise slowed down at the global

308 scale, leaving prominent ice sheets only in Greenland, Iceland, and Antarctica (Lambeck and Chappell,

309 2001) (Fig. 3f). Continuing melting of the Antarctic ice sheet might have lasted until 4.0 cal. kyr BP 
310 (Yokoyama et al., 2012). In the case of Japan, located away from major ice-loading effects, regional/local

311 sea level changes have been caused by either tectonic or isostatic causes (Fig. 3f).

Based upon the topography with the distribution of shell middens, it is known that the lowland in

313 Kanto of eastern Japan was flooded by seawater in 6.5-5.5 cal. kyr BP. This was the period when Corbicula

314 japonica lived in brackish water more than $100 \mathrm{~km}$ away from the present-day shoreline and both corals

315 and warm bivalves occurred at temperatures about $2^{\circ} \mathrm{C}$ higher than the present (Fig. 1a) (Matsushima,

316 2006). Tanabe et al. (2012) reconstructed detailed time-series sea level change in this area, where the sea

317 level rose rapidly in the deglaciation period and slowly reached its highest in 7.4-4.5 cal. kyr BP by $+4.0 \mathrm{~m}$

318 relative to the modern level (Tanabe et al., 2012) (Fig. 3f). On the other hand, the high precision field

319 surveys demonstrated a broad maximum of the sea level (up to $+1.3 \mathrm{~m}$ ) at eastern Hokkaido (Akkeshi Bay),

320 northern Japan, in 6.0 4.0 cal. kyr BP (Shigeno et al., 2013) (Figs. 1a, 3f). However, the alkenone SSTs

321 peaked in 4.7-4.3 cal. kyr BP in Funka Bay and 4.9-4.2 cal. kyr BP in Mutsu Bay (Kawahata et al., 2009b)

322 (Fig. 3a). Therefore, it is suggested that the Mid-Holocene Hypsithermal environment was associated with

323 high stand of sea level in eastern and northern Japan in a broad frame but not in exactly the same time

324 (Figs. 1a, 1b, 3f).

This warming period confirmed in Mutsu and Funka Bays in northern Japan can be associated with a broad increase in sunspot numbers (Fig. 3a, 3c). The numbers estimated from variations in tree ring $\Delta^{14} \mathrm{C}$ generally provide a good proxy for solar radiation (Fig. 3e). When sunspot numbers increase, the sun is brighter and the solar output increases (Usoskin et al. 2007). Lower levels of solar radiation could be related to a significant climatic cooling (Timmreck et al., 2009). Therefore, the Mid-Holocene warm climate could be partly attributed to the enhanced solar activity. However, another factor is required because solar radiation alone is too small to explain such warm environments during this period.

The Japanese archipelago has been influenced by the East Asian Summer Monsoon (EASM). According to a simulation study, the EASM was significantly enhanced during the mid-Holocene and

334 characterized by increased southerly winds in eastern China (Liu et al. 2014). Nagashima et al. (2013) 335 analyzed spatial variations in EASM precipitation to evaluate the westerly jet path over East Asia during 336 the Holocene (Fig. 3d). They found that the contribution of dust from the Mongolian Gobi Desert relative 337 to that from the Taklimakan Desert showed millennial-scale to multi-millennial-scale broad minima at 6.0$3384.6 \mathrm{cal}$. kyr BP, which could be attributed to the earlier seasonal northward progression of the westerly jet.

339 This was associated with the westerly jet shifted northward earlier in the year, resulting in earlier northward 340 migration of the EASM rain-band with heat energy (Fig. 3d). Therefore, it is suggested that the Mid-

341 Holocene Hypsithermal in eastern and northern Japan could be affected mainly by enhanced EASM and solar activity. 
344 Matsushima, northern Honshu, indicated that the sea level rose to $+0.7 \sim+2.1 \mathrm{~m}$ at about $4.0 \sim 3.5 \mathrm{cal}$. kyr BP

345 (Fujimoto, 1990; Yokoyama et al., 2012). Strictly speaking, these lines of evidence demonstrated that the

346 timing of sea-level highstand have differed from place to place in eastern and northern Japan. Sea level for

347 the last $7 \mathrm{kyrs}$ have been controlled mainly by local/regional tectonic vertical movement while

348 Hypsithermal environments could have been influenced by EASM and solar activity in Japan.

\section{$349 \quad$ 4.2ka event in Funka Bay}

The $4.2 \mathrm{ka}$ event is famous for a mid/low-latitude aridification event at the boundary between the mid-Holocene, Northgrippian, and the late-Holocene, Meghalayan (Mayewski et al., 2004; Staubwasser and Weiss, 2006; Walker et al., 2012) but its forcing mechanism remains less obvious than is the case with that at $8.2 \mathrm{ka}$ event. In Funka Bay, alkenone SSTs (ATs) showed definite cooling by $2-3^{\circ} \mathrm{C}$ at this event.

354 Kawahata (2019) discussed the climatic mechanism behind the event based upon the environmental factors in Mutsu Bay, and concluded that southward shift of the westerly jet, in association with a weakened East Asian Summer Monsoon, could cause a relatively cool climate.

ENSO, one of the most important climate phenomena on the Earth, fluctuated largely during the Holocene (e.g., Wu and Liu, 2004; Wang et al., 2005; Hu et al., 2008). The Southern Oscillation Index (SOI) is a proxy for an ENSO event, with negative and positive values corresponding to an El Niño and La Niña episodes, respectively. Although the Japanese islands face western North Pacific, they have received significant influences by a coupled ocean-atmosphere climate phenomenon in the tropical Pacific. In general, during an El Niño episode, the Pacific high is weakened, with reduced atmospheric pressure in the vicinity of Japan. This result in an enhanced Okhotsk high, which tends to be accompanied by a cold and cloudy/rainy summer in Japan (Meteorological Agency of Japan, 2014). In the case of La Niña episodes, the effect is reversal.

The ENSO cycles from 20.0 cal. kyr BP to the present were semi-quantitatively reconstructed in spite of low precision (Rein et al., 2005). The weak El Niño condition was rather stable throughout the mid-Holocene period ( 8.0 - 5.2 cal. kyr BP), which was followed by a major shift to stronger El Niño activities from 5.2 to 3.6 cal. kyr BP. This change from the La Niña to El Niño conditions might have been responsible for the large decline of AT from 4.5 to 4.1 cal. kyr BP. At 4.2ka event, the onset of aridification coincided with a $1-2^{\circ} \mathrm{C}$ cooling of North Atlantic surface waters (Bond et al., 1997), which could bring cooling of tropical 'deep' waters in the tropical Pacific. It has cooled sufficiently to switch-on the El Niño -

373 like condition (Sun, 2000). This condition could weaken the Asian monsoon across 4.1 ka BP (Fisher et al., 374 2008). At least the $4.2 \mathrm{ka}$ event in northern Japan could be characterized by cooling by a few degrees by the 375 combination of reduced ESAM and El Niño mode. 
377

378

379

380

381

382

383

384

385

386

387

388

389

390

391

392

393

394

395

396

397

398

399

400

401

402

403

404

405

406

407

408

Another Hypsithermal environment occurred at $1.2 \mathrm{cal}$. kyr BP in the late Holocene with a maximum temperature of $23.2^{\circ} \mathrm{C}$, comparable with that observed at Mutsu Bay (Figs. 1 and 3a). After that, the SSTs rapidly decreased and showed a large minimum in Funka Bay. This indicates that the Japanese archipelago never experienced the Medieval Warm Event but a Medieval Cool Event, which have already reported from both Hiroshima and Tokyo Bays (Kawahata et al., 2017b; Kajita et al., 2018). In the case of the MidHolocene Hypsithermal environment, EASM could have played an important role in transporting heat energy from the lower to higher latitudes in the western Pacific. Although similar situation could have occurred in 3.5-1.5 cal. kyr BP, ESR Intensity, average summer insolation and sunspot number never showed sharp peaks at 1.2 cal. kyr BP, at the SST maximum in Funka Bay (Nagashima et al., 2013) (Fig. $3 b, 3 c, 3 d)$.

Recently, proxy-based reconstructions of the SOI on a multi-decadal scale became available for the last 2 kyrs (Fig. 3e). As mentioned before, the Japanese archipelago tends to have cooler and hotter summer at El Niño and La Niña conditions, respectively. La Niña condition and its corresponding SST in Funka Bay peaked at 1.20 cal. kyr BP. After that, both SOI and alkenone SST rapidly decreased to El Niño conditions and down to $18.6^{\circ} \mathrm{C}$ in 300 years. This SST fluctuation between 1.4 and 0.9 cal. kyr BP can be verified by historical documents in and around the ancient capital city of Kyoto, western central Japan (Ishii, 2002).

In contrast to Japan, Europe tends to have warm summer at El Niño condition (https://www.data.jma.go.jp/gmd/cpd/data/elnino/learning/tenkou/sekai1 html). The warm summer prevailed in 1.95-1.55 and 0.95-0.60 cal. kyr BP. The former period appreciably corresponded to the Roma Warm Period (1.90-1.55 cal. kyr BP) and the latter to the Medieval Warm Period (0.95-0.65 cal. kyr BP) (Mann et al., 2009; Büntgen et al., 2016). In contrast, La Niña condition corresponded to the Dark Ages Cold Period (1.45-1.05 cal. kyr BP) and the LIA (0.55-0.10 cal. kyr BP) (Büntgen et al., 2016). Therefore, it is suggested that the SOI and AT co-varied in Europe. As pointed by the IPCC Assessment Reports (2001, 2007), Bradley et al. (2003) and Mann et al. (2009), it is suggested that the warmest medieval ATs might have been local/regional, not synchronous around the globe. Reduced solar activities (the Oort Minimum) during a part of the period of $0.94-0.87$ cal. kyr BP could partially contribute to a decrease in temperature during this period, too.

Volcanic forcing is often pointed as an important factor in sudden cooling events. By compiling a historical weather description for 1670-1985AD in northern Japan, a meteorologist Kondo (2000) reported that damage to crops from cold weather occurred 39 times and that 24 of these events were related to large volcanic eruptions within and outside Japan. However, alkenone SST in Ko-d tephra originating from Mt. 
Komagatake at $1640 \mathrm{AD}$ never resulted in cooling episodes but rather it led to enhanced SSTs (Figs 2 and 3a). The reduced temperature of 1.0-0.7 cal. kyr BP could be attributed to the Little Ice Age.

\section{Implications for the relationships between AT and human activities}

\section{Prosperity of the Okhotsk culture in warm climate in Hokkaido}

414 The Okhotsk culture was a coastal fishing and hunting-gathering culture in the Sea of Okhotsk area 415 dated to the $3^{\text {th }}-13^{\text {th }}$ centuries AD. In Hokkaido, Okhotsk archaeological sites are dated to the $5^{\text {th }}-9^{\text {th }}$ 416 centuries. The Hokkaido Okhotsk sites was contemporaneous with Epi- Jomon $\left(3^{\text {th }}\right.$ century BC-7 ${ }^{\text {th }}$ century $417 \mathrm{AD})$ and Satsumon $\left(7^{\text {th }}-12^{\text {th }}\right.$ century AD) sites in the other areas of Hokkaido, but characteristics of these 418 cultures are distinct from each other. Scholars suggest that the bear rituals of the historic Ainu culture 419 originated from the Okhotsk culture. Recent studies on genetic analysis suggest that to major ancestral 420 groups for the historic Ainu people were Jomon and Okhotsk peoples (Adachi et al. 2011;Adachi et al. 421 2012; Takigawa 2012; Shinoda 2015; Sakitani, 2018).

422 Okhotsk subsistence strategy has traditionally been classified as a specialized system of marine 423 resource gathering. Carbon and nitrogen stable isotope analysis of skeletal remains from Okhotsk culture 424 sites indicates that the relative contribution of marine protein was more than $60 \%$ (e.g., whale, seal, 425 salmon) (Naito et al., 2010). However, archaeological data also indicate that their diet was complemented 426 by terrestrial mammals (e.g., domestic pigs, deer, and rabbits) and grains, including barley.

The alkenone SSTs around Funka Bay increased from $18.4^{\circ} \mathrm{C}$ at $89 \mathrm{AD}$, peaked at $23.2^{\circ} \mathrm{C}$ in $759 \mathrm{AD}$ and decreased $17.4^{\circ} \mathrm{C}$ at $1080 \mathrm{AD}$. It is striking that the warm period overlaps with the prosperity of the Okhotsk culture in Hokkaido from the $5^{\text {th }}$ to the $9^{\text {th }}$ centuries, which corresponds to the most Hypsithermal period for the last 2000 years. Today, the Sea of Okhotsk is known for its abundant ice floe formation at the lowest latitude in the world. Cold air from Siberia in winter forms sea ice in the northwestern Sea of Okhotsk. As the ice forms, it expels salt into the deeper layers. This heavy water promotes vertical mixing of coastal water, upwelling of nutrients to the surface, enhancing spring bloom, and bringing abundant sea

434 life. It supports a strong food chain: phytoplankton bloom nourished zooplanktons such as krill, which are 435 the diet of small fishes and shells. They are eaten by large fish, seal, and birds. Therefore, the Sea of 436 Okhotsk is one of the world's richest areas in terms of biological resources.

437 When the climate cools down, the ice floes cover sea surface for a longer period, which prevents 438 people from fishing in the coastal region. In addition, farming, including livestock-farming, becomes more 439 difficult to be operated. The Amur River, the world's tenth longest river (4,350km) with the catchment area 440 of $2.05 \times 10^{6} \mathrm{~km}^{2}$, is so nourishing that its basin is home to a variety of large predatory fish. Lower AT tends 441 to reduce vapor pressure of water to bring less rainfall, to decline terrestrial weathering and to reduce

442 nutrients supply from river to the coastal region. At those times, these effects could deteriorate fishing and 443 hunting. The most prosperous period of the Okhotsk culture could have been blessed with the security of 
444 balanced food supplies from both marine and terrestrial environments. Therefore, it is likely that the

445 Okhotsk culture prospered only under the warm climatic condition and that the culture was eventually

446 absorbed by the Satsumon culture.

447

448 Predominance of marine products as a diet of Jomon people around Funka Bay

Alkenone temperature data demonstrated that the Jomon people in Funka Bay in Hokkaido experienced colder climate than those at the Sannai-Maruyama site in Aomori Prefecture, the largest Jomon settlement (5.9 to 4.3 cal. kyr BP ) (Fig. 3a). Marine products, such as fish and shellfish, must have been abundant while the productivity of terrestrial food declined during the colder phase. It is well known that the colder surface ocean generally promotes marine productivity due to more nutrient supply to the surface ocean by vertical mixing (e.g., Kawahata et al., 2009a). As such, modern Funka Bay provides rich fishing grounds, including those for scallop farming. The Tsugaru and Oyashio Currents enter the bay clockwise in summer and counterclockwise in winter respectively. In accordance with ocean currents, whales and seals move seasonally. Carbon and nitrogen isotopic analyses of proteins extracted from Jomon skeletal remains at Kitakogane, Usu, and Irie-Takasago around Funka Bay demonstrated that the diet consisted primarily of marine fish (including anadromous fish such as salmon), marine bottom fish (e.g., flounder, flatfish) and large marine animals (https://jomon-japan.jp/jomon-sites/ofune/). Jomon residents of this area were more dependent on marine products than Jomon people in Honshu, where two thirds of their nutrition came from terrestrial harvests such as plants, including nuts, and terrestrial animals (e.g., Minagawa et al., 2006). This difference in the dietary trend is basically consistent with the colder climate around Funka Bay than in Honshu.

\section{Implications for human societies in Japan after 3.0 cal. kyr BP}

The mid-latitudes are important areas for the development of early complex societies and civilizations (e.g., Fan, 2009; Hodell et al., 2001). Our research is focused on climatic change back through to 3 cal. kyr BP, around which a major wave of migration started from Continental Asia to the Japanese archipelago (Fig. 4). Early societies on the Japanese islands in the last $3.0 \mathrm{kyr}$ can be divided broadly into 6 phases : 1 ) the Jomon period (before the $10^{\text {th }}-5^{\text {th }}$ century BC),. 2) the Yayoi period $\left(10^{\text {th }}-5^{\text {th }}\right.$ century BC- ca. $250 \mathrm{AD}$ ), when paddy-rice cultivation and other new technologies were introduced together with waves of many immigrants from continental Asia, followed by rapid social stratification (Sato, 2001, 2002; Kawase, 2006; Kono, 2006), 3) the Kofun period (ca. 250-592 AD), the period of early state formation under the strong influences of continental immigrants during and after the 5th century $\mathrm{AD}$, primarily from the Korean Peninsula (Miyamoto, 2009), 4) the Yamato State and Aristocracy period (592-1185 AD), which was the era of centralized states, with many continental immigrants during the $6^{\text {th }}-8^{\text {th }}$ centuries, many of whom were from China (Seki, 2009) 5) the Feudal period (1185-1868 AD), when samurai, the warrior class, were 
479 in charge of political power, and 6) the Modern period (1868 AD to the present) (e.g., Kono, 2006). The

480 SSTs reconstructed at Hiroshima Bay suggest that notable cold periods appeared to coincide with major

481 shifts in social systems in Japan (Kawahata et al., 2017a).

482 The minimal SSTs at Hiroshima Bay generally responded to those at Funka Bay: $6^{\text {th }}-7^{\text {th }}$ century BC,

$4833^{\text {rd }}$ century BC, $6^{\text {th }}$ century AD, $10^{\text {th }}-12^{\text {h }}$ century AD and $16^{\text {th }}$ century AD (Fig. 4). The first cold period

484 corresponded to the gradual transition from the Jomon to the Yayoi periods in western Japan. The cold

485 episode at the $3^{\text {rd }}$ century BC might correspond roughly to the boundary from the Early to the Middle

486 Yayoi period, during which the use of bronze and iron artifacts became more common. The cold event of

487 the $3^{\text {rd }}$ century seems to match the beginning of the Kofun period but the age precision for the $2^{\text {nd }}-3^{\text {rd }}$

488 centuries is not enough. The Yamato State was established and flourished with increased agricultural

489 production in the improved climatic condition, but its political power declined at the time of the cold

490 conditions (Watanabe, 2009). A major cooling episode coincided with the decline of the Yamato state's

491 political power, and it was eventually replaced by the military-based samurai shogunate systems.

492 As pointed in Kawahata et al. (2017a, b), it is likely that the minima in SSTs (ATs) played an

493 important role in serving as an impetus for societal changes. While this possibility has been discussed in

494 several studies (e.g., deMenocal, 2001; Haug et al., 2003), we do not know the precise mechanisms behind

495 the social upheavals discussed above. Economic and sociocultural factors, including agricultural food

496 production, forestry, fishery and other economic activities, as well as political factors such as military

497 occupation and the development of social hierarchy and classes, must also have played significant roles. In

498 order to understand these processes, quantitative data of other climate parameters, such as rainfall,

499 humidity, and cloudiness, will be helpful.

500

501

\section{Conclusions}

502

This paper aimed to enhance our understanding of the Holocene climatic change and to examine the relationship between climatic changes and the human activity in the Holocene in northern Japan, including Hokkaido.

505 1) The SSTs (ATs) in Funka Bay in Hokkaido, northern Japan, ranged from $14.5^{\circ} \mathrm{C}\left(15.7^{\circ} \mathrm{C}\right)$ to $23.2^{\circ} \mathrm{C}\left(22.6^{\circ} \mathrm{C}\right)$ with the difference of $8.7^{\circ} \mathrm{C}\left(6.9^{\circ} \mathrm{C}\right)$. Major maximal SSTs (ATs) were observed around 4.6, 1.2 cal. kyr BP and the present day.

2) Since the SSTs (ATs) observed in Funka Bay were generally lower than those in northern Honshu, the results are consistent with archaeological data that the Hokkaido Jomon people were more dependent on marine resources than those in Honshu.

511 3) Two Hypsithermal episodes were identified around Funka Bay. The $1^{\text {st }}$ Hypsithermal condition

512 generally corresponded to the warm period of 5.9-4.2 cal. kyr BP in Mutsu Bay in Aomori

513 Prefecture, where the Sannai Maruyama settlement flourished. After this warm period, northern 
514 Japan experienced the 4.2ka event, a large-scale cooling climate by a few degrees, which was 515 caused by the combination of reduced ESAM and El Niño mode.

516 4) The $2^{\text {nd }}$ Hypsithermal condition of the $5^{\text {th }}-9^{\text {th }}$ centuries $A D$ could have provided a favorable 517 condition for the Okhotsk culture to prosper along the cost of the Okhotsk Sea in Hokkaido. A 518 notable cooling event occurred around $1.0 \mathrm{cal}$. kyr BP due to La Niña condition and reduced solar 519 activities. As reported in Hiroshima and Tokyo Bays, the Japanese archipelago never experienced 520 the Medieval Warm Event, but instead the presence of a Medieval Cold Event was identified. 521 
523 Abbreviations

524 SST: sea surface temperatures; AT: atmospheric temperature; EASM: East Asian

525 Summer Monsoon.

526

\section{Declarations}

\section{Ethics approval and consent to participate}

529 There is no part on human participants, human data or human tissue in this manuscript.

530 Also this manuscript does not report on or involve the use of any animal or human data 531 or tissue.

\section{2 - Consent for publication}

533 There is no other individual person's data in any form (including individual details,

534 images or videos).

535 This manuscript does not contain any individual personal data.

536 - Competing interests

537 HK has no competing interest.

\section{8 - Availability of data and materials}

539 Data and Materials were collected by Kenji Nishina, analyzed by Hodaka Kawahata 540 under his scientific funds.

541 But, If some would like to share HK's samples, Please contact author for data requests."

\section{2 - Authors' information}

543 No special information for HK.

544 - Funding

545 This work was supported by JSPS KAKENHI Grant Number 1934014622224009,

$54615 \mathrm{H} 02139$ and 20H01981 to HK and by JSPS KAKENHI Grant Number

547 JSPS 26284125 and 18 H00749 to T.A.. Funding for the radiocarbon dates by Beta

548 Analytic was provided by the "Long-term Sustainability through Place-Based, Small-

549 Scale Economies: Approaches from Historical Ecology" project (No. 14200084) at the

550 Research Institute for Humanity and Nature.

\section{1 - Authors' contributions}

552 HK proposed and designed the study. K Nishina collected the sedimentary core. Y

553 Hatta, H Kajita, Y Ota analyzed alkenone. A Yoshida, T Aono and J Habu contributed 554 the discussion on the Jomon period. 
556 We are grateful to Ms. Nishikura at the University of Tokyo for helping us analyze

557 alkenones. Funding for the radiocarbon dates by Beta Analytic was provided by the

558 "Long-term Sustainability through Place-Based, Small-Scale Economies: Approaches

559 from Historical Ecology" project (No. 14200084) at the Research Institute for Humanity

560 and Nature. This research was partly supported by Grants-in-Aid from the Japan Society

561 for the Promotion of Science to H.K. (Nos. 1934014622224009, 15H02139 and

562 20H01981) and to T.A. (JSPS 26284125 and 18H00749).

563

564 References

565 Adachi N, Shinoda K, Umetsu K, Kitano T, Matsumura H, Fujiyama R, Sawada J, Tanaka M 566 (2011) Mitochondrial DNA analysis of Hokkaido Jomon skeletons: Remnants of archaic 567 maternal lineages at the southwestern edge of former Beringia. American Journal Physical 568 Anthropology 146:346-360. Doi.org/10.1002/ajpa.21561

569 Adachi N (2012) Investigation of a genotype of "Emishi" - the analysis of ancient people living

570 in Tohoku area, northern Japan-. Shimin-no-Kokogaku (Archaeology for citizens) 12:95-104

$571 \quad$ (in Japanese)

572 Akamatsu M, Yamazaki S, Arakawa T (1995) Characteristic of the shellfish assemblage during 573 Holocene in Hokkaido. Bulletin of Memorial Hall for the reclamation in Hokkaido, 23:7-18

$574 \quad$ (in Japanese)

575 Aono T (2013) Kitakogane. Date City Institute of Funka culture Report, 1-201

576 Aono T (2017) Environmental changes based upon shell composition of Jomon shell mound

577 along the coast of Funka Bay (Preliminary report). Hokkaido archeology, 53:43-58

578 Berger A (1978) Long-term variations of daily insolation and quaternary climatic changes.

579 Journal Atmospheric Science 35:2362-2367

580 Bond G, Showers W, Cheseby M, Lotti-Bond R, Almasi P, deMenocal P, Priore P, Cullen HR,

581 Hajdas I, Bonani G (1997) A pervasive millennial-scale cycle in North Atlantic Holocene

582 and glacial climates. Science 278:1257-1266

583 Bradley RS, Hughes MK, Diaz HF (2003) "CLIMATE CHANGE: Climate in Medieval Time".

584 Science 302:404-5. doi:10.1126/science.1090372.PMID 14563996

585 Büntgen U, Myglan VS, Charpentier F, Jungqvist L, McCormick M, Cosmo ND, Sigl M,

586 Jungclaus J, Wagner S, Krusic PJ, Esper J, Kaplan JO, de Vaan MAC, Luterbacher J, 
deMenocal P (2001) Culture responses to climate change during the late Holocene. Science 292: $667-673$

Dykoski CA, Edwards RL, Cheng H, Yuan D, Cai Y, Zhang M, Lin Y, Qing J, An Z, Revenaugh J (2005) A high-resolution, absolute-dated Holocene and deglacial Asian monsoon record from Dongge Cave, China. Earth Planetary Science Letters 233:71-86

Emile-Geay J, Seager R, Cane RA, Cook ER, Haug GH (2008) Volcanoes and the ENSO over the Past Millennium. Journal of Climate 21:3134-3147

Fan KW (2009) Climatic change and dynastic cycles in Chinese history: A review essay. Climate Change doi: 10.1007/s10584-009-9702-3

599

Fisher D, Osterberg E, Dyke A, et al. (2008) The Mt Logan Holocene-late Wisconsinan isotope

600 record: tropical Pacific-Yukon connections. The Holocene 18:1-11

601

Fujimoto K (1990) Sea level change during the late Quaternary in Japanese islands. Ph.D.

602 thesis., Tohoku university

603

Fujio S, Imamura M, Nishimoto T (2005) The beginning data of Yayoi period - the establishment of high-resolution dating by Accelerator Mass Spectrometry. Sokendai review of cultural and social studies 1:73-96

606

Geological Survey of Japan (2017) Volcanoes of Japan. https://gbank.gsj.jp/volcano/index.htm

607

Hagino K, Okada H, Matsuoka H (2005) Coccolithophore assemblages and morphotypes of

608 Emiliania huxleyi in the boundary zone between the cold Oyashio and warm Kuroshio

609 currents off the coast of Japan. Marine Micropaleontology. 55:19-47

610 Habu J (2008) A growth and decline in complex hunter-gatherer societies: a case study from the 611 Jomon period Sannai Maruyama site, Japan. Antiquity 82:571-583

612 Haug GH, Günther D, Peterson LC, Sigman MD, Hughen KA, Aeschlimann B (2003) Climate

613 and the collapse of Maya civilization. Science 299:1731-1735

614 He M, Zheng H, Clift PD, Tada R, Wu W, Luo C (2015) Geochemistry of fine grained

615 sediments in the Yangtze River and the implications for provenance and chemical

616 weathering in East Asia. Progress in Earth and Planetary Science 2:32, doi:10.1186/s40645-

617 015-0061-6

618 Hodell D, Brenner AM, Curtis JH, et al. (2001) Solar forcing of drought frequency in the Maya 619 lowlands. Science 292:1367-1370 
Hokkaido Research Organization, National Institute of Advanced Industrial Science and

Technology (2011) Report of Active fault investigation in coastal areas, Kurosatsunai lowland fault zone (marine extension), https://jishin.go.jp/main/chousakenkyuu/engankaiiki/h22/h22 kuromatsunai.pdf

Horikawa K, Kodaira T, Zhang J, Murayama M (2015) $\delta^{18}$ Osw estimate for Globigerinoides ruber from core-top sediments in the East China Sea. Progress in Earth and Planetary Science 2:19 DOI 10.1186/s40645-015-0048-3

Hu C, Henderson GM, Huanga J, Xiea S, Sun Y, Johnson KR (2008) Quantification of Holocene Asian monsoon rainfall from spatially separated cave records. Earth and Planetary Science Letters 266:221-232

IPCC Assessment Report (2001) http://www.grida.no/publications/other/ipcc tar/ IPCC Assessment Report (2007) http://www.ipcc.ch/publications_and_data/ar4/syr/en/contents.html.

Ishii K (2002) Murasaki-shikubu as a certified weather forecaster in Heian period. Kodannsha Co. Ltd., 1-222 (in Japanese)

Japan Meteorological Institute (2015) https://weather.time-j.net/Stations/JP/muroran

Kajita H, Kawahata H, Wang K, Zheng H, Yang S, Ohkouchi N, Utsunomiya M, Zhou B, Zheng B (2018) Extraordinary cold episodes during the mid-Holocene in the Yangtze delta: Interruption of the earliest rice cultivating civilization. Quaternary Science Reviews, 201:418-428. Doi. 10.1016/j.quascirev.2018.10.035

Kajita H, Harada N, Yokoyama Y, Sato M, Ogawa N, Miyairi Y, Sawada C, Suzuki A, Kawahata H (2020) High time-resolution alkenone paleotemperature variations in Tokyo Bay during the Meghalayan: Implications for cold climates and social unrest in Japan. Quaternary Science Reviews 230:106-160

Kariya Y, Alki K, Takaoka S (2016) A middle Holocene wide-spread tephra, Towada-Chuseri, discovered from a subalpine soil on Mount Aizu-komagatake and the Gassan volcano, northern Japan. The Quaternary Research (Daiyonki-Kenkyu) 55:237-246 (in Japanese with English abstract)

Katsuki Y, Suzuki T, Soya T, Yoshihisa Y (1989) Hokkaido-Komagatake Volcano. Geological Survey of Japan. https://gbank.gsj.jp/volcano/Act Vol/hokkaidokomagatake/index-e.html Kaufman DS; Ager TA, Anderson NJ, Anderson PM, Andrews JT, Bartlein PJ; Brubaker LB, Coats LL, Cwynar LC, Duvall ML, Dyke AS, Edwards ME, Eisner WR, Gajewski K, Geirsdottir A, Hu FS, Jennings AE, Kaplan MR, Kerwin MW, Lozhkin AV, MacDonald ; 

JP, Steig EJ, Wolfe BB (2004). "Holocene thermal maximum in the western Arctic (0-180 W)"(PDF). Quaternary Science Reviews. 23:529-560

Kawahata H (2019) Climatic reconstruction at the Sannai-Maruyama site between Bond events 4 and 3 Implication for the collapse of the society at 4.2 ka event -. Progress in Earth and Planetary Science, 6:63 /doi.org/10.1186/s40645-019-0308-8

Kawahata H, Yamamoto H, Ohkuchi K, Yokoyama Y, Kimoto K, Ohshima H, Matsuzaki H

Kawahata H, Minoshima K, Ishizaki Y, Yamaoka K, Gupta LP, Nagao M, Kuroyanagi A (2009a) Comparison of settling particles and sediments at IMAGES coring site in the northwestern North Pacific - effect of resuspended particles on paleorecords. Sedimentary Geology 222:254-262

(2009b) Changes of environments and human activity at the Sannai-Maruyama ruins in Japan during the mid-Holocene Hypsithermal climatic interval. Quaternary Science Reviews 28:964-974

Kawahata H, Ishizaki Y, Kuroyanagi A, Suzuki A, Ohkushi K (2017a) Quantitative reconstruction of temperature at Jomon site in the Incipient Jomon period in northern Japan and its implication for the production of early pottery and stone arrowheads. Quaternary Science Reviews 157:66-79, Doi: 10.1016/j.quascirev.2016.12.009

Kawahata H, Matsuoka M, Togami A, Harada N, Murayama M, Yokoyama Y, Miyairi Y, Matsuzaki H, Tanaka Y (2017b) Climatic change and its influence on human society in western Japan during the Holocene. Quaternary International 440:102-117. DOI:10.1016/j.quaint.2016.04.013

Kawahata H, Fujita K, Iguchi A, Inoue M, Iwasaki S, Kuroyanagi A, Maeda A, Manaka T, Moriya K, Takagi H, Toyofuku T, Yoshimura T, Suzuki A (2019) Perspective on the response of marine calcifiers to global warming and ocean acidification - Behavior of corals and foraminifera in a high CO2 world "hot house". Progress in Earth and Planetary Science 6:5, doi10.1186/s40645-018-0239-9

Kawahata H, Okamoto T, Matsumoto E, Ujiie H (2000) Fluctuations of eolian flux and ocean productivity in the mid-latitude north Pacific during the last 200 kyr. Quaternary Science Reviews 19:1279-1291

Kawase M (2006) A shell mound in Kibi area. Kibito Publishing Co. Ltd., 1-167 (in Japanese) 
Kito N, Noda T, Minami T (1998) Holocene Fluctuation of the Warm Tsushima Current and

Warm Molluscan Assemblages from Hokkaido, Japan. The Quaternary Research (DaiyonkiKenkyu) 37:25-32 (in Japanese with English abstract)

Kondo J (1987) Science for Common Weather Flow of Heat Energy. Tokyo University Press, p. 189 (in Japanese)

690

Kondo J (2000) Atmospheric Science Close to Earth's Surface. Tokyo University Press, pp. 1-

691 336 (in Japanese).

692

Kono Y (2006) Japanese history, Kodanshha Japan. 1-229 (in Japanese).

693

Kuroyanagi A, Kawahata H, Narita H, Ohkushi K, Aramaki T (2006) Reconstruction of paleoenvironmental changes based on the planktonic foraminiferal assemblages off Shimokita in the northwestern North Pacific. Global and Planetary Change 53:92-107

696

Lambeck K, Chappell J (2001) Sea level change through the last glacial cycle. Science

697 292:679-686

Liu Z, Wne X, Brady EC, Otto-Bliesner B, Yu G, Lu H, Cheng H, Wang Y, Zheng W, Ding Y,

698

699

700

701

702

703

704

705

706

707

708

709

710

711

712

713 Edwards RL, Cheng J (2014) Chinese cave records and the East Asia Summer Monsoon. Quaternary Science Review 83:115-128

Mann ME, Zhang Z, Rutherford S, Bradley RS, Hughes MK, Shindell D, Ammann C, Faluvegi G, Ni F (2009) Origins of the Little Ice Age and Medieval Climate Anomaly. Science 326, 1256-1260, doi:10.1126/science.1177303. PMID 19965474

Matsushima Y (2006) Jomon transgression deduced from shell deposits. Yurindo, Yokohama, $1-216$

Mayewski PA, Rohling EE, Stager JC, Karlén W, Maasch KA, Meeker LD, Meyerson EA, Gasse F, van Kreveld S, Holmgren K, Lee-Thorp J, Rosqvist G, Rack F, Staubwasser M, Schneider RR, Steig EJ (2004) Holocene climate variability. Qua- ternary Research 62:243255

Meteorological Agency of Japan (2014) http://www.data.jma.go.jp/gmd/cpd/data/elnino/learning/tenkou/nihon1 html

Minagawa M (2006) When did the Japanese start to use a marine resource? Marine Chemistry 19:94-100 (in Japanese)

Minoshima K, Kawahata H, Ikehara K (2007) Changes in biological production in the mixed water region (MWR) of the northwestern North Pacific during the last $27 \mathrm{kyr}$ Palaeogeography Palaeoclimatology Palaeoecology 254:430-447 
Miyake H, Kakihara M, Fujiyoshi Y, Matsuoka M (1977) Turbidity distribution in the Funka Bay for the period of inflow of the Tsugaru warm water. 28, 154-164. Bulletin of the Faculty of Fisheries Hokkaido University 28:154-164

Miyazono A, Nishina K (2007) Vertical distribution of toxic dinoflagellate Alexandrium spp. resting cysts in the sediments from Funka Bay, Hokkaido. Bulletin Plankton Society. Japan, 54:85-91

Müller PJ, Kirst G, Ruhland G, Storch I, von Rossell-Méle A (1998) Calibration of the alkenone paleotemperature index Uk'37 based on core-tops from the eastern South Atlantic and the global ocean $\left(60^{\circ} \mathrm{N}-60^{\circ} \mathrm{S}\right)$. Geochimica Cosmochimica Acta 62:1757-1772

Nagashima K, Tada R, Toyoda S (2013) Westerly jet-East Asian summer monsoon connection during the Holocene, Geochemistry Geophysics Geosystem 14: doi:10.1002/2013GC004931 Naito Y, Chikaraishi Y, Ohkouchi N, Mukai H , Shibata Y, Honch N V , Dodo Y, Ishida H , Amano T , Ono H , Yoneda M (2010) Dietary Reconstruction of the Okhotsk Culture of Hokkaido, Japan, Based on Nitrogen Composition of Amino Acids: Implications for Correction of 14C Marine Reservoir Effects on Human Bones. Radiocarbon 52: 671-681 Nakamura Y (2016) Stratigraphy, distribution, and petrographic properties of Holocene tephras in Hokkaido, northern Japan. Quaternary International 397:52-62

Nakanishi R, Okamura S (2019) Tsunami deposits from the 1640 Hokkaido Komagatake eruption, north Japan: constrains on inundation heights and numerical simulation of volcanic debris avalanche-derived tsunami. Journal of Geological Society of Japan 125:835-851

Parker AG, Goudie AS, Stokes S, White K, Hodson MJ, Manning M, Kennet D (2006) A record of Holocene climate change from lake geochemical analyses in southeastern Arabia. Quaternary Research 66:465-476

Prahl FG, Muehlhausen LA, Zahnle DL (1988) Further evaluation of long-chain alkenones as indicators of paleoceanographic conditions. Geochimica Cosmochimica Acta 52, 2302-2310 Ramsey CB, Lee S (2013) Recent and planned developments of the program Oxcal, 2013. Radiocarbon 55:720-730

Reimer PJ, Bard E, Bayliss A, Beck JW, Blackwell PG, Ramsey CB, Buck CE, Cheng H, Edwards RL, Friendrich M, Grootes PM, Guilderson TP, Haflidason H, Hajdas I, Hatte C, Heaton T, Hoffmann D, Hogg AG, Hughen KA, Kaiser KF, Kromer B, Manning SW, Niu M, Reimer RW, Richards DA, Scott EM, Southon JR, Staff RA, Turney CSM, van der Plicht Jphannes (2013) INTCAL13 and MARINE13 radiocarbon age calibration curves 050,000 years CAL BP. Radiocarbon 55:1869-1887 
Riel S (2008) Climate and agriculture in the ancient Near East: a synthesis of the archaeobotanical and stable carbon isotope evidence. Vegetation History and Archaeobotany 17:43-51, DOI: 10.1007/s00334-008-0156-8

Rein B, Luckge A, Reinhardt L, Sirocko F, Wolf A, Dullo W-C (2005) El Niño variability off Peru during the last 20,000 years. Paleoceanography 20, PA4003, 1-17, doi:10.1029/2004PA001099, 2005

Sato Y (2001) Paddy rice civilization based upon DNA analysis. NHK books-773, Tokyo, 1227 (in Japanese)

Sato Y (2002) History of Japanese paddy rice. Kadokawa Co. Ltd., 1-197 (in Japanese)

Sagawa T, Kuwae M, Tsuruoka K, Nakamura Y, Ikehara M, Murayama M (2014) Solar forcing of centennial-scale East Asian winter monsoon variability in the mid- to late Holocene, Earth and Planetary Science Letters 395:124-135

Sakitani M (2018) Trip of Japanese for 100,000 years traced by the analysis of DNA. Showado, Kyoto,1-208, (in Japanese)

Seki A (2009) Immigrants to Japan -Talking about ancient politics, economy and culture. Kodansha Academic Library, 1-256, ISBN 978-4-06-291953-1 (in Japanese)

Sekine T (2014) Changes in the number of archaeological sites during the Jomon Period in Aomori Prefecture, northeastern Japan. The Quaternary Research (Daiyonki-Kenkyu) 53:193-203 (Japanese with English abstract)

Shigeno K, Nanayama F, Sudo Y, Sagayama T, Hasegawa T, Ando H (2013) Reconstructed Holocene sea level curve from the Akkeshi barrier system in eastern Hokkaido, Japan. Journal Geological Society Japan, 119:171-189

Shinoda K (2015) Origin of Japanese based upon DNA. Iwanami Modern Compendium, 1-245. Iwanami, Tokyo ISBN : 9784000291736 (in Japanese)

Stanley JD, Krom MD, Cliff RA, Woodward JC (2003) Short Contribution: Nile Flow Failure at the End of the Old Kingdom, Egypt: Strontium Isotopic and Petrologic Evidence. Geoarchaeology: An International Journal 18:395-402

Staubwasser M, Weiss H (2006) Holocene climate and cultural evolution in late prehistoricearly historic West Asia. Quaternary Research 66:372-387

Sun D (2000) Global climate change and El Niño: a theoretical framework. In Diaz HF, Markgraf V (eds) El Niño and Southern Oscillation. Cambridge University Press: Cambridge; 443-463 
781

782

783

784

785

786

787

788

789

790

791

792

793

794

795

796

797

798

799

800

801

802

803

804

805

806

807

808

809

810

811

812

Tada R, Murray RW (2016a) Land-Ocean Linkages under the Influence of the Asian Monsoon. Progress in Earth and Planetary Science 3:24, DOI: 10.1186/s40645-016-0100-y

Tada R, Zheng H, Clift PD (2016b) Evolution and variability of the Asian monsoon and its potential linkage with uplift of the Himalaya and Tibetan Plateau. Progress in Earth and Planetary Science. 3: 4, DOI: 10.1186/s40645-016-0080-y

Takahashi W, Hiwatari T, Fukushima H, Toratani M, Akano T (1995) High-reflectance waters of possible Coccolithophore blooms in NW Pacific -analysis of 1979-86 Nimbus-7/CZCS data set. Oceanography Japan 4:477-486 (in Japanese)

Takei T, Minoura K, Tsukawaki S, Nakamura T (2002) Intrusion of a branch of the Oyashio Current into the Japan Sea during the Holocene. Paleoceanography 17:11-1-10

Takigawa W (2012) Bone Archaeology on Emishi and Hayato. Doseisha, Tokyo 1-194

Tanabe R, Nakashima R, Uchida M, Shibata Y (2012) Depositional process of an estuary mouth shoal identified in the Alluvium of the Tokyo Lowland along the Tokyo Bay, central JapanJour. Geolocial Society Japan 118:1-19

Taniguchi Y (2006) Dating and function of the oldest pottery in Japan. Current Research in the Pleistocene. 23:33-35

Timmreck C, Lorenz SJ, Crowley TJ, Kinne S, Raddatz TJ, Thomas MA, Jungclaus JH (2009) Limited temperature response to the very large AD 1258 volcanic eruption. Geophysical Research Letters 36:L21708, doi:10.1029/2009GL040083

Usoskin IG, Solanki SK, Kovaltsov GA (2007) Grand minima and maxima of solar activity: new observational constraints. Astronomy and Astrophysics 471:301-309. DOI: 10.1051/00046361:20077704

Villanueva J, Grimalt JO (1997) Gas chromatographic tuning of the UK'37 paleothermometer. Analytical Chemistry 69:3329-3332

Walker MJC, Berkelhammer M, Bjorck S, Cwynar LC, Fisher DA, Long AJ, Lowe JJ, Newnham RM, Rasmussen SO, Weiss H (2012) Formal subdivision of the Holocene Series/Epoch: a Discussion Paper by a Working Group of INTIMATE (Integration of icecore, marine and terrestrial records) and the Subcommission on Quaternary Stratigraphy (International Commission on Stratigraphy). Journal of Quaternary Science 27:649-659 Wang Y, Cheng H, Edwards RL, He Y, Kong X, An Z, Wu J, Kelly MJ, Dykoski CA, Li X (2005) The Holocene Asian monsoon: Links to the changes and North Atlantic climate. Science 308:854-857 
813 Wang LB, Yang ZS, Zhang RP, Fan DJ, Zhao MX, Hu BQ (2011) Sea surface temperature

814 records of core ZY2 from the central mud area in the South Yellow Sea during last 6200

815 years and related effect of the Yellow Sea Warm Current. Chinese Science Bulletin

$816 \quad 56: 1588-1595$

817 Watanabe A (2009) Century of Heijokyo and wooden strip. Japanese history 04, Kodansha

$818 \quad$ Academic Library, 1-391

819 Weiss H, Courty MA, Wetterstrom W (1993) The genesis and collapse of third millennium

$820 \quad$ North Mesopotamian civilization. Science 261:995-1004

821 Wu WX, Liu TS (2004) Possible role of the "Holocene Event 3" on the collapse of neolithic

822 cultures around the Central Plain of China. Quaternary International 117:153-166

823 Yamamoto M, Shimamoto A, Fukuhara T, Naraoka H, Tanaka Y, Nishimura A (2007) Seasonal

824 and depth variations in molecular and isotopic alkenone composition of sinking particles

825 from the western North Pacific. Deep-Sea Research Part 1, 54:1571-1592

826 Yamamoto M (2009) Response of mid-latitude North Pacific surface temperatures to orbital

827 forcing and linkage to the East Asian summer monsoon and tropical ocean-atmosphere

828 interactions. Journal Quaternary Science 24:836-847

829 Yan H, Sun L, Wang Y, Huang W, Qiu S, Yang C (2011) A record of the Southern Oscillation

$830 \quad$ Index for the past 2,000 years from precipitation proxies. Nature Geoscience 4:611-614

831 Yokoyama Y, Okubo J, Miyairi Y, Obrochta S, Demboya N, Makino Y, Kawahata H (2012)

832 Holocene sea-level change and Antarctic melting history derived from geological

833 observations and geophysical modeling along the Shimokita Peninsula. Geophysical

834 Research Letters 39:L13502, doi:10.1029/2012GL051983

835 Yoneda M, Uno H, Shibata Y, Suzuki R, Kumamoto Y, Yoshida K, Sasaki T, Suzuki A,

836 Kawahata H (2007) Radiocarbon marine reservoir ages in the western Pacific estimated by

837 pre-bomb molluscan shells. Nuclear Instrument Method B 259:432-437

838 Yoshino M (2009a) Climatic Change and Human Activities in the 4th to 10th Centuries.

839 Journal Geography 118:1221-1236

840 Yoshino M (2009b) Development of bioclimatological thought in Japan from ancient times to

$841 \quad$ Present. Global Environmental Research 13:5-12

842 Zhang C (2013) "The Qujialing-Shijiahe culture in the middle Yangzi River valley", in

843 Underhill, Anne P., A Companion to Chinese Archaeology, John Wiley \& Sons, pp. 510-

$844 \quad 534$, ISBN 978-1-118-32578-0

845 
Figure captions

847

848 Figure 1(a). Map of the western North Pacific and Japan Sea near the Japanese Islands. The

849 paths of the Kuroshio, Tsushima, Tsugaru and Oyashio Currents are also shown. The location of

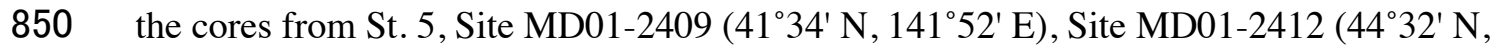
$\left.851145^{\circ} 00^{\prime} \mathrm{E}\right), \mathrm{PC} 02$ site $\left(41^{\circ} 00^{\prime} \mathrm{N}, 140^{\circ} 46^{\prime} \mathrm{E}\right)$ and of the sediment trap position at Site MD018522409 (Kuroyanagi et al., 2006; Kawahata et al., 2009a, 2009b). (b) Major Jomon site locations:

853 Ofune (Earth to Middle Jomon), Kakinoshima Site (Initial to Late Jomon), Kitakogane (Early 854 Jomon) and Irie-Takasago (Early to Finanl Jomon), Odai-Yamamao I Site (Incipient Jomon), 855 and Sannai-Maruyama (Early-Middle Jomon), Jomon periods for 14,200 years are classified into 856 six sub-periods: Incipient (16.5-11.55 cal. kyr BP), Initial (11.55-6.95 cal. kyr BP), Early (6.958575.47 cal. kyr BP), Middle (5.47-4.42 cal. kyr BP), Late (4.42-3.22 cal. kyr BP), and Final (3.228582.90 cal. kyr BP) (Habu, 2004; Sekine, 2014; Kawahata et al., 2017a).

859 Figure 2. Schematic representation of the visually observed lithology and magnetic 860 susceptibility (MS) of core St. 5, with calendar ages. Dating was determined using AMS ${ }^{14} \mathrm{C}$ 861 dating of plants and molluscan shells. All ${ }^{14} \mathrm{C}$ ages were calibrated to calendar ages and it was 862 assumed no difference of $\Delta R$ because Funka Bay is more isolated from open ocean than 863 Tsugaru Strait. The sediments were precipitated at very constant rate $\left(r^{2}=0.997\right.$ between depth 864 and age) from the bottom to $46 \mathrm{~cm}$ depth (Ko-d tephra originating from the Komagatake at 1640 865 AD). The ages above the Ko volcanic ash are approximate.

866 Figure 3. Time series records of (a) C37 alkenone SSTs (ATs) at St. 5 (solid circle) and SSTs 867 and SSTs (ATs) at PC02 site (line) in Mutsu Bay (solid square) (Kawahata et al., 2009b), (b)

868 The summer and winter daily insolation at $55^{\circ} \mathrm{N}$ in the Northern Hemisphere for the last 8,000 869 years (W m ${ }^{-2}$ ) (Berger, 1978), (c) sunspot number (Usoskin et al., 2007), (d) ESR intensity of 870 fine silt-sized quartz particles in Japan Sea sediments with vertical shading showing negative 871 peaks (Nagashima et al., 2013), which is a proxy for the latitudinal shift of Westerly Jet stream, 872 related to latitudinal shift of East Asian Monsoon, (e) $\delta^{18} \mathrm{O}$ of the Dongge and Hulu Cave 873 stalagmites as a proxy for the intensity of the Far Eastern Asian Summer Monsoon (Dykoski et 874 al., 2005), (f) Southern Oscillation Index (SOI)-like index for the last 2 kyr (Yan et al., 2011) 875 and lithic down-core variation off Peru as a proxy for SOI in 2-8 cal kyr BP (Rein et al., 2005),

876 (g) global sea level change (bold line: Tanabe et al., 2012; dotted line: Shigeno et al., 2013; 
877 Thin line: Lambeck and Chappell, 2001). The first upper column shows culture in Hokkaido:

878 Ainu (modern-13 $3^{\text {th }}$ century), Satsumon ( $13^{\text {th }}-7^{\text {th }}$ century), Post- Jomon $\left(7^{\text {th }}\right.$ AD $-3^{\text {th }}$ BC century)

879 and Jomon (before $3^{\text {th }}$ century). The second upper column represent Jomon sub-periods (Initial

880 (11.55-6.95 cal kyr BP), Early (6.95-5.47 cal kyr BP), Middle (5.47-4.42 cal kyr BP), Late

881 (4.42-3.22 cal kyr BP), and Final (3.22-2.90 cal kyr BP) (Habu, 2004; Sekine, 2014). The age of

882 the SSTs (ATs) data after 1640AD are approximate.

883

884 Figure 4. Time series of alkenone sea surface temperature (SST) and atmospheric temperature

885 (AT) during the last 3,000 years in Hiroshima (a, circle) and Funka (b, solid square) Bays. The

886 gray color area, after 1640AD, in Funka Bay indicated that the age of the SSTs (ATs) data is

887 approximate. Upper column shows each period with broad category of social system. The life

888 style in ancient society in Japan is classified broadly into six groups. Three main immigration

889 intervals are also plotted. Italic characters, representing volcanic eruption, show possible causes.

890 Upper solid triangles represent possible volcanic eruption. Especially the large eruption in 1258

891 AD was identified in Ice cores and sediments but the source is mysterious (Emile-Geay et al.,

892 2008). Gray curves in $1000 \mathrm{BC}-400 \mathrm{BC}$, in 600-1400 AD and in 1750-1850 AD represent $\mathrm{C}_{37}$

893 alkenone SSTs in Yellow Sea (Wang et al., 2011), qualitative AT estimate from the historical

894 documents (Ishii, 2002; Yoshino, 2009a, b) and semi-quantitative AT estimate from the

895 historical documents (Kondo, 1987), respectively. All famines shown here represent a

896 widespread scarcity of food, caused by cold climate. Three severe famines in Medieval times

897 include Yowa (1180AD), Kangi (1230 AD) and Kansho (1460 AD) while four severe famines

898 in northern Japan in Edo period include Kanei (1642-43 AD), Horeki (1755-57), Tenmei

899 (1782-87 AD), and Tenpo (1833-39 AD). Middle column shows periods of culture in

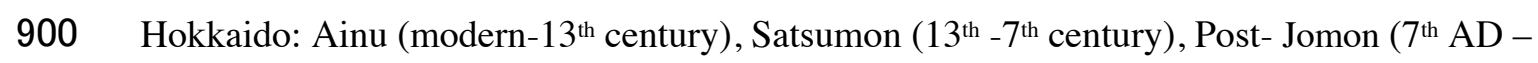

$9013^{\text {th }}$ BC century) and Jomon (before $3^{\text {th }}$ century). An arrow in Figure (b) shows Okhotsk culture in

902 Hokkaido in $5^{\text {th }}-9^{\text {th }}$ centuries. Arrows on the bottom represent Roman Warm Period (RWP, 50-

903400 AD), Medieval Warm Period (MWP, ca. 950-1250 AD [sometimes 1000-1400]), Dark

904 Ages Cold Period (AD 500-900) and Little Ice Age (LIA, ca. 1600-1850 AD [sometimes

905 1350-1850]) have received much attention (e.g., Yan et al., 2011

906 Figure 1 

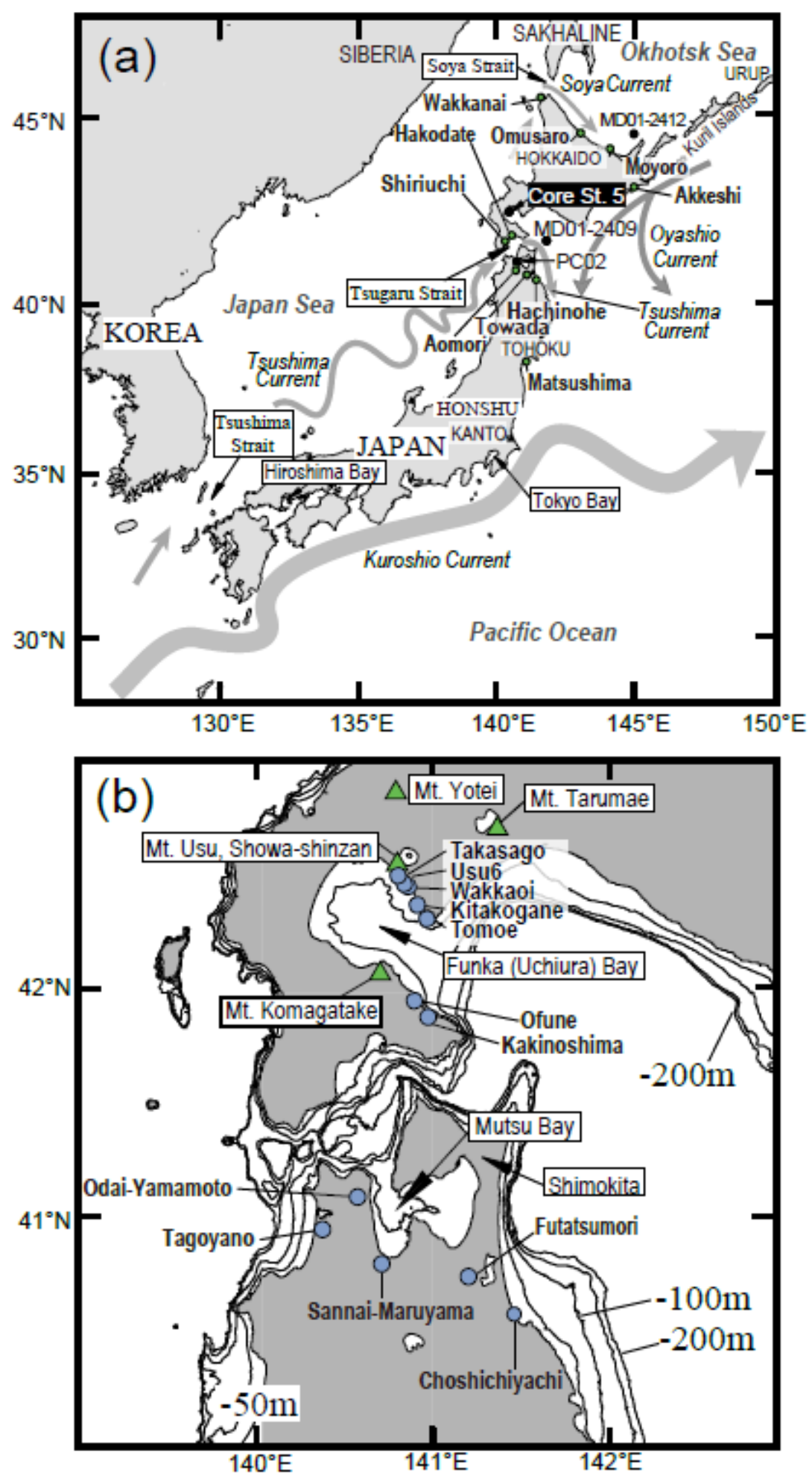

\section{Figure 1}

(a). Map of the western North Pacific and Japan Sea near the Japanese Islands. The paths of the Kuroshio, Tsushima, Tsugaru and Oyashio Currents are also shown. The location of the cores from St. 5,

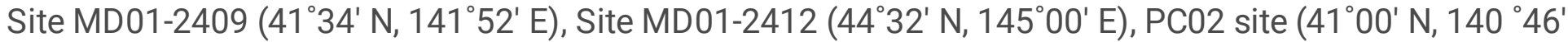


E) and of the sediment trap position at Site MD01- 2409 (Kuroyanagi et al., 2006; Kawahata et al., 2009a, 2009b). (b) Major Jomon site locations: Ofune (Earth to Middle Jomon), Kakinoshima Site (Initial to Late Jomon), Kitakogane (Early Jomon) and Irie-Takasago (Early to Finanl Jomon), Odai-Yamamao I Site (Incipient Jomon), and Sannai-Maruyama (Early-Middle Jomon), Jomon periods for 14,200 years are classified intosix sub-periods: Incipient (16.5-11.55 cal. kyr BP), Initial (11.55-6.95 cal. kyr BP), Early (6.955.47 cal. kyr BP), Middle (5.47-4.42 cal. kyr BP), Late (4.42-3.22 cal. kyr BP), and Final (3.22- $2.90 \mathrm{cal}$. kyr BP) (Habu, 2004; Sekine, 2014; Kawahata et al., 2017a).

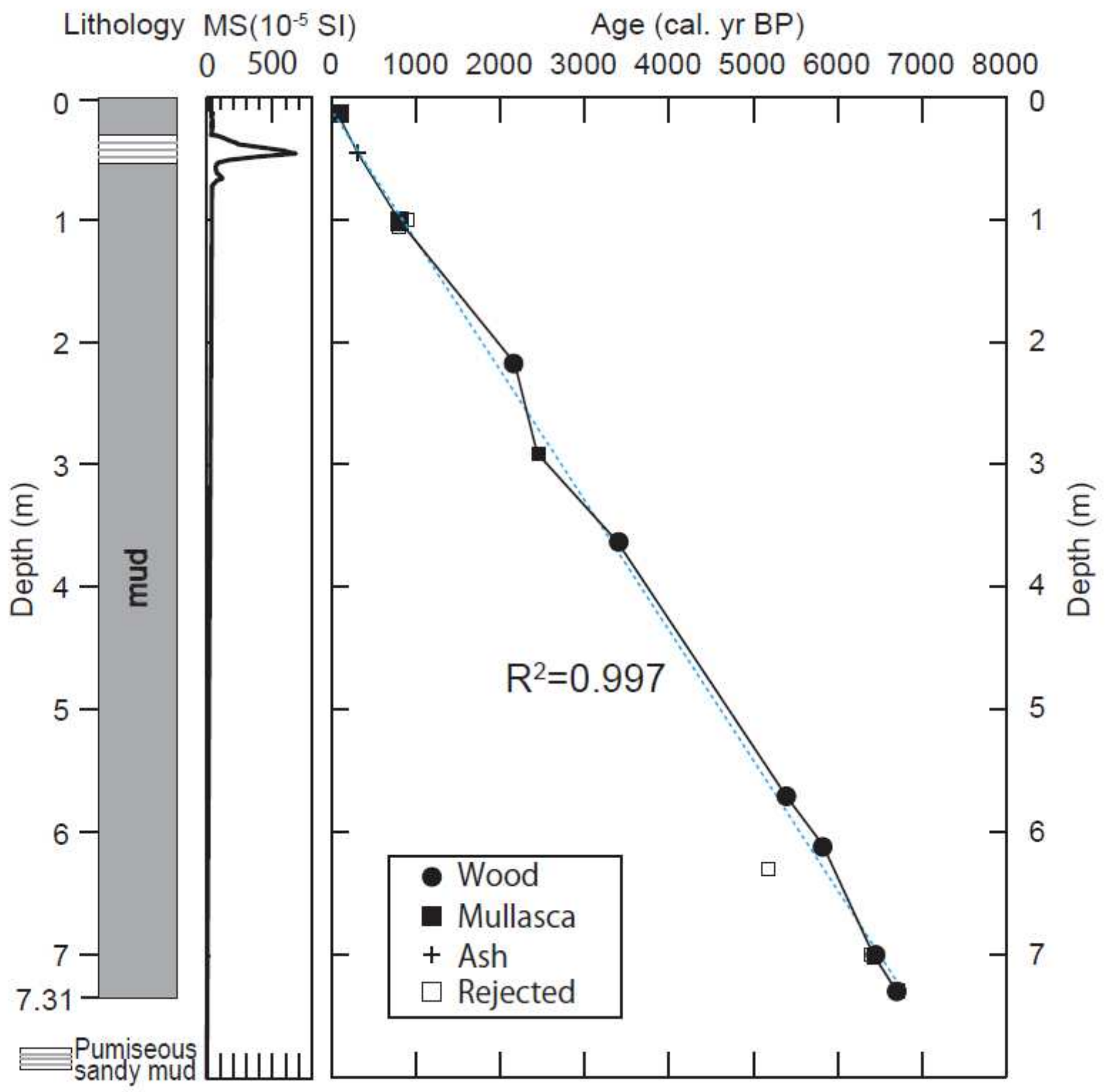

Figure 2 
Schematic representation of the visually observed lithology and magnetic susceptibility (MS) of core St. 5, with calendar ages. Dating was determined using AMS 14C dating of plants and molluscan shells. All $14 \mathrm{C}$ ages were calibrated to calendar ages and it was assumed no difference of $\Delta R$ because Funka Bay is more isolated from open ocean than Tsugaru Strait. The sediments were precipitated at very constant rate $(r 2=0.997$ between depth and age) from the bottom to $46 \mathrm{~cm}$ depth (Ko-d tephra originating from the Komagatake at $1640 \mathrm{AD}$ ). The ages above the Ko volcanic ash are approximate.
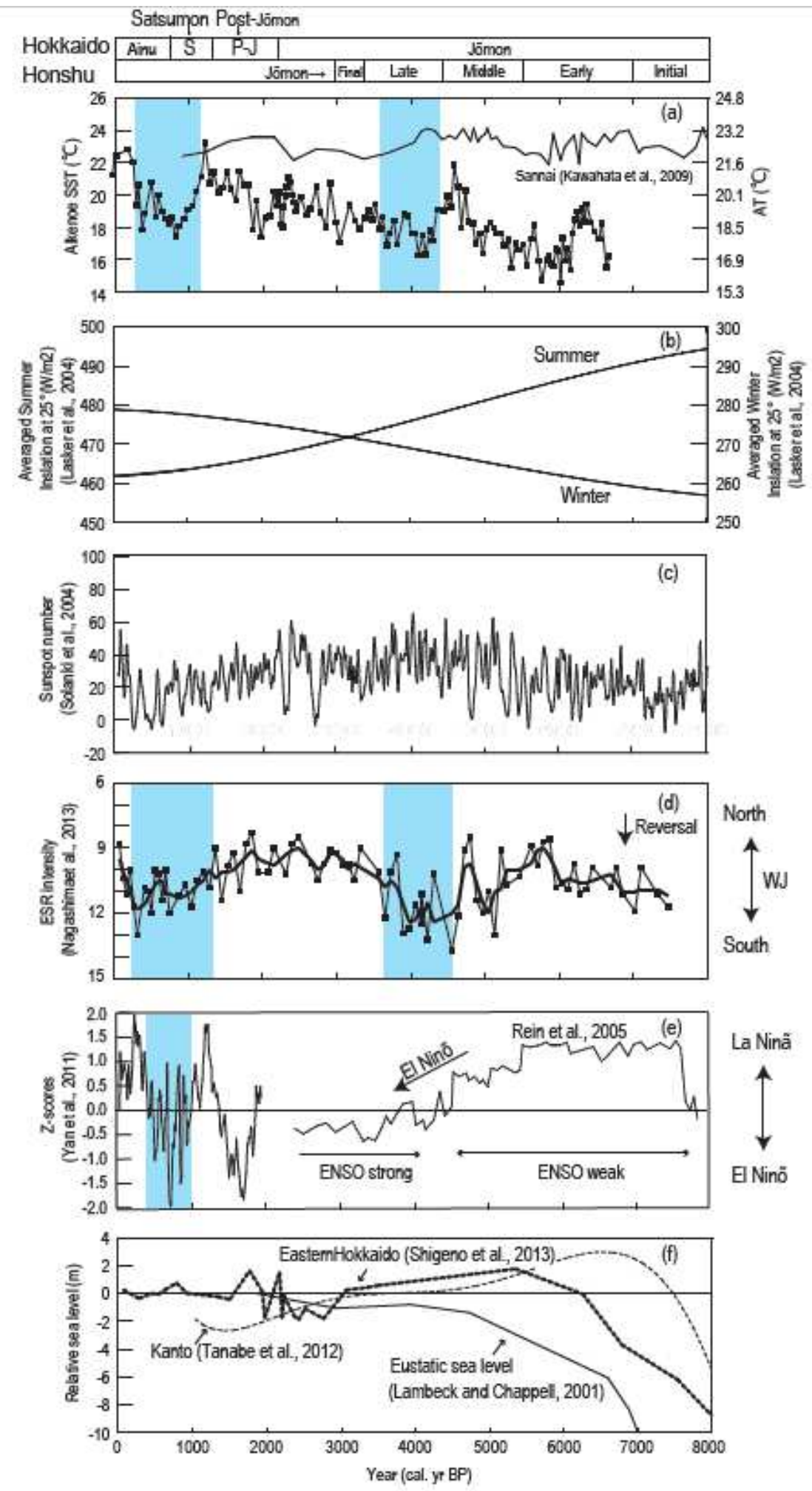

Figure 3 
Time series records of (a) C37 alkenone SSTs (ATs) at St. 5 (solid circle) and SSTs and SSTs (ATs) at PC02 site (line) in Mutsu Bay (solid square) (Kawahata et al., 2009b), (b) The summer and winter daily insolation at $55^{\circ} \mathrm{N}$ in the Northern Hemisphere for the last 8,000 years (W m-2) (Berger, 1978), (c) sunspot number (Usoskin et al., 2007), (d) ESR intensity of fine silt-sized quartz particles in Japan Sea sediments with vertical shading showing negative peaks (Nagashima et al., 2013), which is a proxy for the latitudinal shift of Westerly Jet stream, related to latitudinal shift of East Asian Monsoon, (e) $\delta 180$ of the Dongge and Hulu Cave stalagmites as a proxy for the intensity of the Far Eastern Asian Summer Monsoon (Dykoski et al., 2005), (f) Southern Oscillation Index (SOl)-like index for the last 2 kyr (Yan et al., 2011) and lithic down-core variation off Peru as a proxy for SOl in 2-8 cal kyr BP (Rein et al., 2005), (g) global sea level change (bold line: Tanabe et al., 2012; dotted line: Shigeno et al., 2013; Thin line: Lambeck and Chappell, 2001). The first upper column shows culture in Hokkaido: 878 Ainu (modern-13th century), Satsumon (13th -7th century), Post- Jomon (7th AD - 3thBC century) and Jomon (before 3th century). The second upper column represent Jomon sub-periods (Initial (11.55-6.95 cal kyr BP), Early (6.95-5.47 cal kyr BP), Middle (5.47-4.42 cal kyr BP), Late (4.42-3.22 cal kyr BP), and Final (3.22-2.90 cal kyr BP) (Habu, 2004; Sekine, 2014). The age of the SSTs (ATs) data after 1640AD are approximate. 


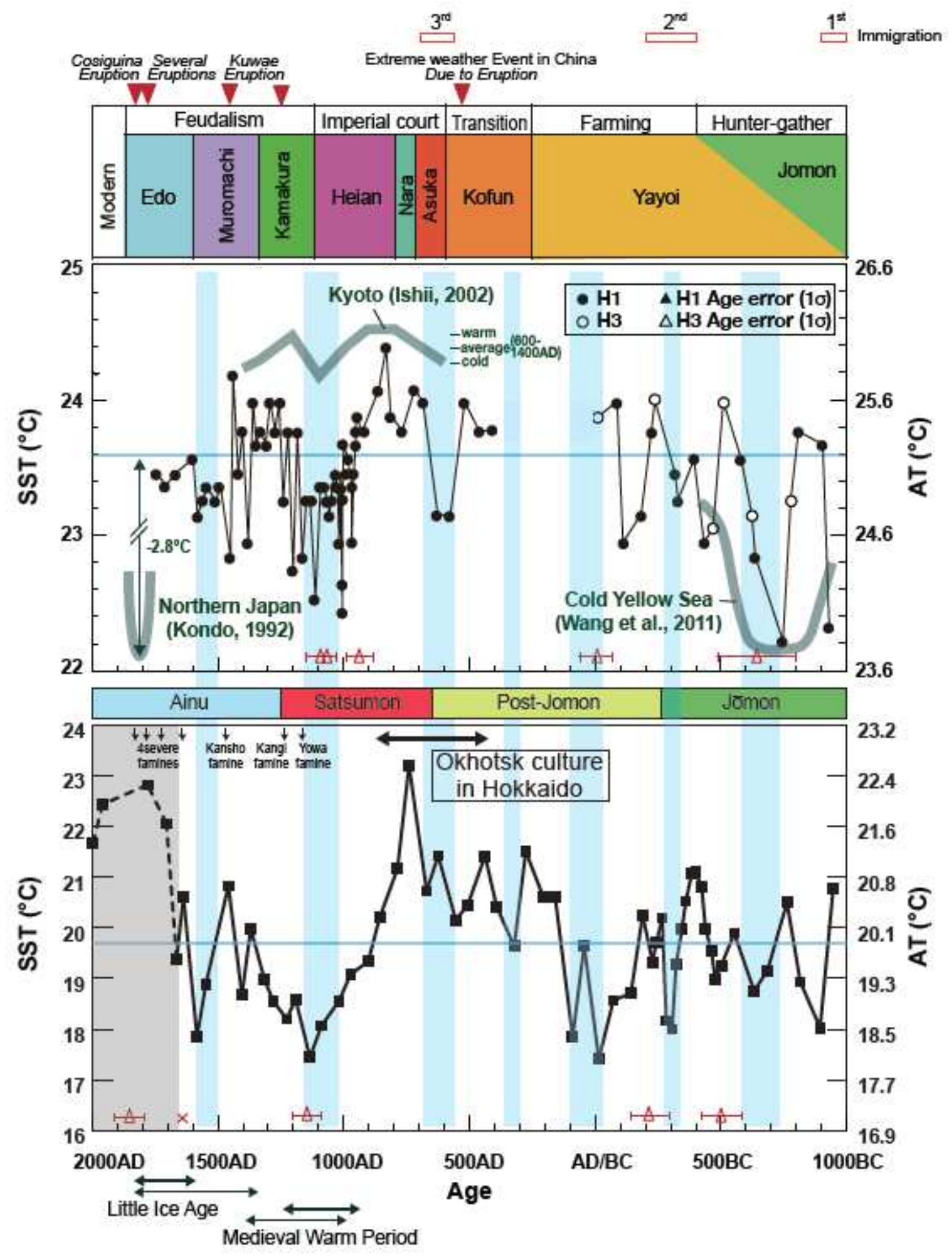

Figure 4

Time series of alkenone sea surface temperature (SST) and atmospheric temperature (AT) during the last 3,000 years in Hiroshima ( $a$, circle) and Funka ( $b$, solid square) Bays. The gray color area, after 1640AD, in Funka Bay indicated that the age of the SSTs (ATs) data is approximate. Upper column shows each period with broad category of social system. The life style in ancient society in Japan is classified broadly into six groups. Three main immigration intervals are also plotted. Italic characters, representing volcanic eruption, show possible causes. Upper solid triangles represent possible volcanic eruption. 
Especially the large eruption in 1258 AD was identified in Ice cores and sediments but the source is mysterious (Emile-Geay et al., 2008). Gray curves in 1000 BC-400 BC, in 600-1400 AD and in 17501850 AD represent C37 alkenone SSTs in Yellow Sea (Wang et al., 2011), qualitative AT estimate from the historical documents (Ishii, 2002; Yoshino, 2009a, b) and semi-quantitative AT estimate from the historical documents (Kondo, 1987), respectively. All famines shown here represent a widespread scarcity of food, caused by cold climate. Three severe famines in Medieval times include Yowa (1180AD), Kangi (1230 AD) and Kansho (1460 AD) while four severe famines in northern Japan in Edo period include Kanei (1642-43 AD), Horeki (1755-57), Tenmei (1782-87 AD), and Tenpo (1833-39 AD). Middle column shows periods of culture in Hokkaido: Ainu (modern-13th century), Satsumon (13th -7th century), PostJomon (7th AD - 3thBC century) and Jomon (before 3th century). An arrow in Figure (b) shows Okhotsk culture in Hokkaido in 5th - 9th centuries. Arrows on the bottom represent Roman Warm Period (RWP, 50400 AD), Medieval Warm Period (MWP, ca. 950-1250 AD [sometimes 1000-1400]), Dark Ages Cold Period (AD 500-900) and Little Ice Age (LIA, ca. 1600-1850 AD [sometimes 1350-1850]) have received much attention (e.g., Yan et al., 2011

\section{Supplementary Files}

This is a list of supplementary files associated with this preprint. Click to download.

- PEPS3E73TableKAW.pdf

- PEPS4E73GraphicalAbstract.pdf 